Egyptian Journal of Aquatic Biology \& Fisheries

Zoology Department, Faculty of Science,

Ain Shams University, Cairo, Egypt.

ISSN $1110-6131$

Vol. 23(5): 137 - 166 (2019)

www.ejabf.journals.ekb.eg

\title{
Revision of Superfamily Pilumnoidea from the Egyptian Red Sea coasts, Gulfs of
} Aqaba and Suez, Egypt

\author{
Awaad, A. M. El-Sayed ${ }^{1}$; Abdullah, M. Abd-ElKhalek ${ }^{1}$; Mohamed, A. Amer ${ }^{1 *}$ \\ and Mostafa, H. Sarhan ${ }^{2}$ \\ 1- Zoology Department, Faculty of Science, Al-Azhar University, Cairo. \\ 2- Zoology Department, Faculty of Science, Al-Azhar University, Assiut. \\ * Corresponding author: naseramer@azhar.edu.eg
}

\section{ARTICLE INFO \\ Article History: \\ Received: Oct. 26, 2019 \\ Accepted:Nov. 25, 2019 \\ Online: Nov. 29, 2019}

Keywords:

Pilumnidae

Galenidae

feather crab

hairy crabs

Red Sea

Egypt

\section{ABSTRACT}

A total of 10 species of superfamily Pilumnoidea belong to families Galenidae and Pilumnidae, distributed within 6 genera were recorded from the coasts of the Red Sea, Gulfs of Suez and Aqaba, in addition to Suez Canal Lakes. Halimede tyche was the only species belong to family Galenidae, while family Pilumnidae was represented by 9 species within five genera comprised Actumnus asper, Cryptopilumnus pereiodontus, Pilumnopeus convexus, Pilumnus incanus, P. longicornis, P. minutus, $P$. propinquus, $P$. vespertilio and Tiaramedon spinosum. Genus Pilumnus was the dominant and represented by 5 species amounting $50 \%$ of the all recorded species. Cryptopilumnus pereiodontus is recorded for first time from the Egyptian waters and the entire Red Sea. A brief description and notes on size, localities, color and habitats and distribution were given. Constructed keys for identification were also provided.

\section{INTRODUCTION}

Superfamily Pilumnoidea is known as "hairy crabs", and was separated from Xanthoidea by Ng et al. (2008). It comprises three well defined families; Galenidae, Pilumnidae and Tanaochelidae (2 species). Family Galenidae was created by Alcock (1898) and comprises 14 species, while family Pilumnidae was previously proposed by Samouelle (1819) and comprised the higher number of species and genera (388 species), but family Tanaochelidae was created by Ng \& Clark (2000) and comprised only 2 species.

The species of this superfamily have carapace varied in shape from hexagonal to transversely rectangular or transversely ovate. The dorsal surface is convex, smooth to granulate with an entire to multilobate frontal margin. Its anterolateral margin beings provided with 1 to 4 teeth or lobes on each. The longitudinal ridges are welldeveloped along entire endostome and defining efferent respiratory current. These ridges are visible on anterior part of the endostome when mouthparts are pushed aside. Chelipeds are semi equal and dissimilar and they have normal ambulatory legs. Male abdominal segments 3 to 5 are freely movable or have seven segments as free. First male pleopod is slender and S-shaped, distal part simple; second male pleopod very short and sigmoid (Garth and Kim, 1983; Naderloo, 2017). Most species of superfamily Pilumnoidea live in different places and habitats from the intertidal to 
subtidal and shallow water with substrates comprised shell fragments, gravel, oyster bank, rocky, cobble, muddy, weeds and mangroves (Naderloo, 2017). The members of these families were treated in several articles around the world in the Indo west Pacific and Indian Oceans including Red Sea. Garth and Kim (1983) listed 29 species from family Pilumnidae under subfamily Pilumninae, of them Pilumnus longicornis and $P$. minutus are widely distributed in the Indo-west Pacific regions including the Red Sea. Guinot (1967) and Vine (1986) listed 23 species within 10 genera among subfamily Pilumninae from the entire Red Sea under family Xanthidae, of them Actumnus asper, P. longicornis, P. propinquus and Pilumnus vespertilio. Recently Naderloo (2017) recorded 25 species belong to 13 genera from Pilumnidae in the Arabian Gulf; of them 6 species in each Actumnus and Pilumnus, and two in both Eurycarcinus and Typhlocarcinus, while the other 9 genera were represented with only on species for each. He indicated that, out of the Arabian Gulf pilumnid, 12 were recorded previously from the Red Sea.

Along the Egyptian coasts of the Red Sea and its associated gulfs (Suez and Aqaba) as well as Suez Canal lakes, pilumnid crabs were treated in few studies under subfamily Pilumninae among family Xanthidae (Fox, 1927; Monod, 1937, 1938; Holthuis, 1956; Guinot, 1967; Vine, 1986; El- Sayed,1992, 1996 a, b; Fouda, 2000; Fouda et al., 2003), or as family Pilumnidae with 5 subfamilies that was represented by Serene (1984), but no detailed studies were carried out on this superfamily in the previously mentioned areas.

Therefore, this study aims at revise all species of superfamily Pilumnoidea along the entire Egyptian coasts of the Red Sea, Gulfs of Suez and Aqaba in addition to their northward distribution in the Suez Canal Lakes.

\section{MATERIALS AND METHODS}

A total of 131 specimens of pilumnid species were investigated and revised during the present study. These specimens were examined among the Reference Collection Al-Azhar University, Egypt (RCAZUE) in addition to that collects recently from the different localities of subtidal and intertidal zones of shallow waters along the Egyptian Red Sea, Gulfs of Aqaba and Suez and Suez Canal. The Egyptian Red Sea coasts were divided to sectors arranged from north to south as: Hurghada- Safaga, Safaga- Qusier, Qusier- Marsa Allam, Marsa Allam- Ras Banas, Ras BanasShalatein, and from Shalatein to Adal Deib southern sector, comprised sandy shores, rocky shores and mangrove swamps along these sectors. In addition to, some specimens from offshore islands as Abu Munkar and Gotat Abu Ramad Islands facing Hurghada were also collected. At South Sinai, the protected areas at Ras Mohamed, the northern tip of the Red Sea, Abu Galloum and Nabq protectorate areas at Gulf of Aqaba comprised Ras Altantor, Almonqataa, Al Rewisaia and Al Gharkana at Nabq and Ras Abu Galloum, Abu Galloum Bay and coasts of Wadi Sakhan, Wadi Hobeaq were surveyed in addition to Taba at the northern tip of Gulf of Aqaba. While at Gulf of Suez (Ain Sokhna, Adabia, Kabanon at the western coast and Ras Suder, Ras Matarma and Hammam Pharaon at the eastern coasts were surveyed. While Lake Timsah and Bitter lakes were surveyed at Suez Cana, in addition to Boghaz Ashtom El Gamil at the entrance of Lake Manzala with Mediterranean Sea during the period from 1986 to 2018.

In the field, date and time of collection as well as all observations on habitat type, site position, tides and zones of collection were noted. 
The subtidal and intertidal inhabiting species were collected by hand directly from their natural occurrence of during snorkeling. The collected specimens were immediately preserved in $10 \%$ formalin and kept in labeled plastic containers, then transferred to the laboratory for identification.

The collected and examined specimens were identified according keys of Barnard (1950), Serene (1984) and Naderloo (20017) and all available literature treated Pilumnidae in the Red Sea and neighboring areas as Garth and Kim (1983) in Arabian Gulf and Gulf of Oman, El Sayed (1992, 1996 a, b, 2002), Hellal et al. (1997), Fouda (2000), Fouda et al., (2003) on the Red Sea and Gulfs of Suez and Aqaba, and Suez Canal Lakes.

The carapace length $(\mathrm{CL})$, carapace width $(\mathrm{CW})$, chela length $(\mathrm{Ch}$. L), finger length (FL), front width (FW), orbital width (OW), and other necessary measurements for all specimens were measured using Vernier caliper. All terminology used in this article follow those mentioned by Barnard (1950), Serene (1984) and Naderloo (2017).

Microscopic investigation and photography of fine details of body regions for small specimens were carried out using a binocular microscope (Model OPTICA, SZM-1) fitted by a Micro-cam (PHD-5 MP) and a portable camera (Samsung HD1080).

\section{RESULTS}

\section{Systematic account}

Superfamily: Pilumnoidea Samouelle, 1819

Family: Galenidae Alcock, 1898

Subfamily: Halimedinae Alcock, 1898

Genus: Halimede De Haan, 1833

Halimede tyche (Herbst, 1801)

Family: Pilumnidae Samouelle, 1819

Subfamily: Pilumninae Samouelle, 1819

Genus: Actumnus Dana, 1851

Actumnus asper (Ruppell, 1830)

Genus: Cryptopilumnus Hsueh, Huang and Ng, 2009

Cryptopilumnus pereiodontus (Davie and Ghani, 1993)

Genus: Pilumnopeus A. Milne-Edwards, 1867

Pilumnopeus convexus (Maccagno, 1936)

Genus: Pilumnus Leach, 1815

Pilumnus incanus (Forskal, 1775)

Pilumnus longicornis Hilgendorf, 1878

Pilumnus minutus (De Haan, 1835)

Pilumnus propinquus Nobili, 1905

Pilumnus vespertilio (Fabricius, 1793)

Genus: Tiaramedon Chia and Ng, 1998

Tiaramedon spinosum (Miers, 1879)

Superfamily: Pilumnoidea Samouelle, 1819

Family: Galenidae Alcock, 1898

Subfamily: Halimedinae Alcock, 1898

Genus: Halimede De Haan, 1833

Halimede tyche (Herbst, 1801)

Synonyms: 
Cancer ochtodes Herbst, 1783: 158, Pl. 8, Fig. 54.

Cancer tyche Herbst, 1801: 35, 36, pl. 52, Fig. 3.

Halimede ochtodes, Rathbun, 1910: 353, pl. 1, Fig. 4; -Stephensen, 1946: 158, Fig 41b-d; -Sakai, 1976: 387, Fig. 208b; -Ghani and Tirmizi, 1992: 41-43, Fig 3a-g;Tirmizi and Ghani, 1996: 37-40, Figs.13, 14;- Osman, 2015: 14-15, Pl. 1 c.

Polycremnus verrucifer, Stimpson, 1907.

Halimede hendersoni Nobili, 1905a: 62; Nobili, 1906a: 123, pl. 6, Fig. 1.

Halimede tyche - Sakai, 1999: 35, Pl. 18 h; -Galil, 2000: 329, 330, Fig. 3a, b; Apel, 2001: 98; -Ng et al., 2008: 138 (list); Naderloo and Sari, 2007a: 344, tab 1; Naderloo, 2017: 291, Fig. 25.4.

Material examined: 20 (13 males and 7 females).

\section{Localities:}

Suez Canal: Great Bitter Lake (Defresoir): RCAZUE-Crus-Br.300101-1, 2 $\hat{\jmath}, 3.15-$ 3.50 (CL), 4.30-4.90 (CW), 1993; RCAZUE-Crus-Br.300101-2, 4๐, 1ㅇ, 2.63-3.62 (CL), 3.52-5.09 (CW); RCAZUE-Crus-Br.300101-3, 1今̄, 19, 2.92-3.90 (CL), 3.965.06 (CW), 11/1995; RCAZUE-Crus-Br.300101-4, 1ð， 3.10×4.25, 7/6/1990; RCAZUE-Crus-Br.300101-5, 3今， 2.30-3.16(CL), 3.04-4.40 (CW), 25/4/1989; RCAZUE-Crus-Br.300101-6, 2§, 5ㅇ, 2.52-3.12(CL),3.34-4.34 (CW), 1992.

\section{Morphological characters:}

Carapace is broader than long, oval and pentagonal in outline shape, beings 1.4 breadth on length. Its surface is provided with lobes separated by broad shallow depressions, but regions are indistinct (Plate I, a). Anterolateral margins are divided into four distinct rounded lobes, increasing in size posteriorly (Plate III, i). Front is pronounced, and has square cut, consisting of two lobes separated by a distinct cleft (Plate III, a).

Third maxilliped is provided with tubercles on merus; few tubercles are also seen on distal part of ischium and exopod; ischium is larger than merus (1.5 in length) and beings grooved longitudinally.

Chelipeds are subequal, with slightly larger right chelae, tuberculated with 3 rows on outer surface, increasing in size posteriorly and one row on upper side increasing anteriorly, being similar to that on anterolateral surface of carapace. Cheliped ischium is provided with fine teeth on inner margin. Fingers have teeth on their cutting edges. Palms and movable fingers have 3-4 unequal triangular tubercles, enlarged towards the proximal end (Plate IV, a).

Walking legs are elongated and have tomentum on outer distal margins of propodi and dactyli. Inner margins of dactyli have bristles, and each ends with claw. Outer margin of meri is characterized with tubercles (Plate V, a).

Male abdomen has seven segments, all are clearly marked, the last segment is tongue-shaped (Plate V, g).

First male pleopod is slender, gradually tapering distally, and has a row of minute spines on inner margin (Plate IV, 1); second pleopod is very short than first pleopod, and never exceeds that of the first.

Color: Carapace, dorsal and ventral surfaces of chelipeds and walking legs varied from whitish to creamy or faint brownish.

Habitat: It inhabits mud or sandy-mud bottoms at shallow water underneath stones and also occurs in sea grass beds.

Status: Common.

Distribution:

Local: Red Sea and Suez Canal lakes, Timsah and Bitter Lakes (Vine, 1986; El Sayed, 1992, Osman, 2015). 
World: Indo-Pacific from Japan to East of India, Pakistan and coasts of Arabian Gulf and Arabian Sea (Sakai, 1976; Galil, 2000; Naderloo, 2017).

Remarks: The characters of the present specimens agree well with the description given by Sakai (1976) and Galil (2000). However, finger and thumb are convex and transversally slightly across their tip. Anterolateral margins of carapace are divided into four lobes with outline smooth except third lobe has granules on lower margin. Second male pleopod is shorter than first and without gradually tapering distally, its tip with setae as brush of hairs.

Family: Pilumnidae Samouelle, 1819

Genus: Actumnus Dana, 1851

Actumnus asper (Ruppell, 1830)

Synonyms:

Xantho asper Ruppell, 1830: 21, pl. 4, Fig. 8.

Actumnus bonnieri Nobili, 1905: 163; -Nobili, 1906a: 132, pl. 6, Fig. 32.

Actumnus asper, Stephenson, 1946: 141, 142, 206, Fig. 35c, d; -Guinot, 1967: 272

(list); -Titgen, 1982: 127, 128, 251 (list); -Apel, 2001: 95; -Ng et al., 2008: 139 (list).

Material examined: Only one male.

Localities:

Gulf of Aqaba: Abu Galloum Protected Area: RCAZUE-Crus-Br.640101-1, St. 13, $1{ }^{\Uparrow}, 5.7 \times 7.7 \mathrm{~mm}, 25 / 7 / 1994$.

\section{Morphological characters:}

Carapace is transversely oval, broader than long, beings 1.47 breadth on length. Regions are markedly uneven well-defined, not entirely covered with dense short setae, but have small and not dentiform granules; no setae on furrows of carapace. Upper surface of carapace has velvet form setae, while appendages have scarce of long setae (Plate I, b). Anterolateral margins are convex provided with four spin-form teeth, supplemented with additional small granules; posterolateral margins are semi concave; a distinct junction is found between anterolateral and posterolateral margins (Plate I, b). Front is bilobed, granulated and has slightly convex frontal margin, markedly produced with shallow notch between supra orbital angles and front. Front and inner orbital margin are separated with small lobule (Plate I, b).

Chelipeds are similar in shape and semi equal in size; inner surface of chelae are smooth, with serrated lower margins, while outer surface and proximal third of movable finger have acute granules, (Plate I, b).

Abdomen of male is divided into 7 elongated and narrow segments; telson never reached half of fused sternites 3-4.

Color: Carapace, chelipeds and walking legs are light brown color. Distal third of cheliped finger and thumb have dark brown color. Ventral surface of hepatic and branchial regions have scattered red spots.

Habitat: It occurs in rocky habitats under stones.

Status: Very rare.

Distribution:

Local: Gulf of Aqaba (present results), Red Sea and Gulf of Suez (Ramadan, 1936; Monod, 1938, Vine, 1986).

World: Indo-West Pacific including Arabian Gulf and Gulf of Oman (Nobili, 1905 as Actumnus bonnieri; Stephenson, 1946; Titgen, 1982; Apel, 2001; Naderloo, 2017).

Remarks: The characters of the present specimen are in agreement with those mentioned by Naderloo (2017). However, anterolateral margins have four large spinform teeth being deeply separated and except first tooth beings shallow separated and small. 
Genus: Cryptopilumnus Hsueh, Huang and Ng, 2009

Cryptopilumnus pereiodontus (Davie and Ghani, 1993)

Synonyms:

Pilumnopeus pereiodontus Davie and Ghani, 1993: 61-65, Figs. 1, 2; -Ng et al., 2008: 141 (list).

Cryptopilumnus pereiodontus Hsueh et al., 2009: 328, tab 1; -Naderloo et al., 2016:

3, Fig. 5; -Naderloo, 2017: 301, Figs, 26.9, 26.10a, 26.11.

Material examined: 15 ( 9 males and 6 females).

\section{Localities:}

Red Sea proper: South Marsa ALam: Gabal Altale'a: RCAZUE-Crus-Br.640201-1, $1 亏$, 1 + $, 0.40-0.45 \mathrm{~cm}(\mathrm{CL}), 0.60-0.70 \mathrm{~cm}(\mathrm{CW}), 18 / 9 / 1996$. Hurghada: Mangrove channel of Abu Monqar Island: RCAZUE-Crus-Br.640201-2, $1 O^{\top}, 0.41 \times 0.60 \mathrm{~cm}$, 17/11/1995; Ras Mohamed Protected Area: St. 8, RCAZUE-Crus-Br.640201-3, 2へ, 0.33-0.44 cm (CL), 0.53-0.66 cm (CW), 5/1994. Marsa Alam: 50 Km North Marsa Alam: RCAZUE-Crus-Br.640201-4, 1 ð̄, $0.31 \times 0.50 \mathrm{~cm}, 10 / 9 / 1996$.

Gulf of Aqaba: Abu Galloum Protected Area: RCAZUE-Crus-Br.640201-5, 2ð, 0.30-0.32 cm (CL), 0.50-0.53 cm (CW), 26/11/1994; RCAZUE-Crus-Br.640201-6, $1 \widehat{\jmath}, 2$, $, 0.25-0.42 \mathrm{~cm}(\mathrm{CL}), 0.45-0.65 \mathrm{~cm}(\mathrm{CW}), 25 / 5 / 1995$. Nabq Protected Area: St. 8, RCAZUE-Crus-Br.640201-7, 2ㅇ, 0.30-0.51 cm (CL), 0.50-0.70 cm (CW), 11/1994, St. 20, 1 q, $0.25 \times 0.40 \mathrm{~cm}$; Mangrove Al-Monqataa: RCAZUE-CrusBr.640201-8, 1 (ovigerous), $0.25 \times 0.45 \mathrm{~cm}, 11 / 1994$.

\section{Morphological characters:}

Carapace is hexagonal, broader than long, beings 1.6 breadth on length, without defined regions; upper surface of carapace and appendages have short setae and fine velvet-form setae (Plate I, c). Anterolateral margin is convex, distinctly separated with a prominent junction from the straight posterolateral margin. It provided with relatively 3 low acute and oblique teeth behind exorbital angle (Plate III, j). Front is straight and not markedly produced, without deep notch between supra orbital angles and front. Distance between front and inner orbital margin without lobule (Plate III, b).

Chelipeds are dissimilar and markedly tuberculated on upper and outer surfaces. Large chela is swollen, while small chela is elongate. Fingers of both chelae are convex; cutting margins have obtuse teeth (Plate IV, b \& i).

Walking legs are short, covered with short setae on anterior and posterior margins (Plate V, b).

Abdomen of males is elongated and narrow, divided into 7 segments, covering most of sternite 4 and with a locking mechanism; telson never reaches half of fused sternites 3-4. Genital openings are coxal or coxo-sternal. Transverse suture between sternites 1 and 2 is indistinct in males.

First male pleopod is like S-shaped, naked and tapering (Plate IV, $\mathrm{m}$ ).

Color: Carapace, dorsal and ventral surfaces of chelipeds as well as walking legs are light brown color, fingers and thumbs are dark brown but not prolong on palm.

Habitat: It lives in the intertidal and shallow subtidal zones of both rocky and cobble substrates or underneath rock boulders in mangroves.

Status: Common.

Distribution:

Local: This is the first record for this species from the Egyptian coasts and the entire the Red Sea Red Sea and Gulf of Aqaba.

World: This species occurs in Arabian Gulf, Gulf of Oman and Indian Ocean (Naderloo, 2017). 
Remarks: These characters of the present specimens are in agreement with those described by Naderloo (2017). However, teeth of the anterolateral margins have obliquely tips and no distinct teeth on the posterior margins of ischium and merus of third and fourth walking legs. Large chelae has scattered setae and granules on upper portion, while small chelae has densely setae and granules on all outer surface.

Genus: Pilumnopeus A. Milne-Edwards, 1867

Pilumnopeus convexus (Maccagno, 1936)

Synonyms:

Heteropanope convexa Maccagno, 1936: 176.

Pilumnopeus salomonensis, Ward, 1942: 96; -Davie, 1989: 143.

Pilumnopeus vauquelini, Stephenson, 1946: 141; -Monod, 1938: 141; -El-Sayed, 1992: 68-69, Pls. III, 1, 8 and IV, 1, 8.

Pilumnopeus indica, Barnard, 1955: 30.

Pilumnopeus convexa, Davie, 1989: 142.

Pilumnopeus convexus, Cooper, 1997: 171; -Ng et al., 2008: 141; -Ghory et al., 2013: 303;--Naderloo, 2017: 311, Fig. 26.21, 26.22a, 26.23.

Material examined: 50 (32 males and 18 females).

Localities:

Suez Canal Lakes: Timsah Lake: RCAZUE-Crus-Br.640301-1, 3ึ̂, 1.20-1.58 cm (CL), 1.74-2.42 cm (CW), 1992; RCAZUE-Crus-Br.640301-2, 3ð , 2 9 , 0.92-1.6 cm (CL), 1.33-2.30 cm (CW), 1986.

Red Sea proper: Hurghada Sector: RCAZUE-Crus-Br.640301-3, $1 \delta^{\lambda}, 0.40 \times 0.55 \mathrm{~cm}$, 10/1993; RCAZUE-Crus-Br.640301-4, 20, 1 ㅇ $0.30-0.47 \mathrm{~cm}$ (CL), 0.60-0.80 cm (CW), 2/9/1994; RCAZUE-Crus-Br.640301-5, 10ึ, 1ㅇ, 1.02-1.10 cm (CL), 1.60-1.70 cm (CW), 4/9/2000. Hamata- Barnes: St. 2, RCAZUE-Crus-Br.640301-6, 60, 3 , 0.25-0.42 cm (CL), 0.68-0.93 cm (CW), 19/2/1997; St. 13. RCAZUE-CrusBr.640301-7, 3今े, 1ㅇ, 0.35-0.80 cm (CL), 0.60-1.10 cm (CW), 19/2/1997. QusierMarsa Alam Sector: Alkhema Beach: RCAZUE-Crus-Br.640301-8, 1§̂, 2 + 0.31-0.45 cm (CL), 0.60-0.95 cm (CW), 9/1997. South Shalatein: Mangroves Marsa Abu Fissi: St. 3, RCAZUE-Crus-Br.640301-9, 3今े, 3ㅇ, 0.20-0.65 cm (CL), 0.60-1.00 cm (CW), $16 / 8 / 1999$.

Gulf of Suez: Ain Sokhna: RCAZUE-Crus-Br.640301-10, 2ð, 0.85-0.70 cm (CL), 0.80-0.90 cm (CW), 18/6/1996. Adabia: RCAZUE-Crus-Br.640301-11, 10̄, $0.50 \times 0.64 \mathrm{~cm}, 25 / 10 / 2014$. Hammam Phara'on: RCAZUE-Crus-Br.640301-12, $1 \hat{\jmath}$, $0.73 \times 1.00 \mathrm{~cm}, 23 / 8 / 1990$; RCAZUE-Crus-Br.640301-13, 1 ô, $1.1 \times 1.70 \mathrm{~cm}, 22 / 2 / 2014$; RCAZUE-Crus-Br.640301-14, 2へ, 1.00-1.15 cm (CL), 1.71-1.80 cm (CW), 12/6/2015; RCAZUE-Crus-Br.640301-15, 1 ${ }^{\lambda}, 0.60 \times 0.88 \mathrm{~cm}, 17 / 1 / 2014$; RCAZUECrus-Br.640301-16, 1q, 0.31×0.60 cm, 27/7/1993.

Gulf of Aqaba: Abu Galloum Protected Area: St. 2, RCAZUE-Crus-Br.640301-17, 2 , $, 0.30-0.35 \mathrm{~cm}(\mathrm{CL}), 0.50-0.75 \mathrm{~cm}(\mathrm{CW}), 5 / 1994$. Nabq Protected Area: Ras Altantor: RCAZUE-Crus-Br.640301-18, $1 \hat{\jmath}, 2$ ㅇ $0.20-0.27 \mathrm{~cm}$ (CL), 0.44-0.60 cm (CW), 26/11/1994.

\section{Morphological characters:}

Carapace is hexagonal, broader than long, beings 1.5 breadth on length; carapace regions are identified, dorsal surface with rows of small rounded granules on frontal, gastric, branchial and cardiac regions, in addition to scattered plumose setae of different sizes on branchial regions (Plate I, d). Anterolateral margin has 3 teeth beyond the external orbital angle; the first tooth is blunt and developed, second is sharp but not pointed and third tooth is the sharpest and pointed (Plate III, k). Frontal margin is straight; inner supraorbital tooth with an outer frontal angle forming a V- 
shaped notch in which antenna fits, appears from ventral view of carapace; supraorbital margin without deep notch from dorsal surface of carapace (Plate III, c). Chelipeds are dissimilar and unequal with smooth large chelae and finely granulated small chelae. Carpus has one lobe at distal extremity. Movable fingers are shorter than superior margins of palm, being 3.4 in lengths and have slightly toothed cutting edges (Plate IV, c \& j).

Ambulatory legs are noticeably shorter than chelipeds, beings 0.6 in length and have unarmed coxa, merus, carpus and propodus, covered with long and short dispersed setae; dactylus is slightly curved with slightly tapering tip (Plate V, c).

Abdomen of male consists of 7 free segments with triangular apex telson and covered with fine setae. First and second thoracic sternites are completely fused; second and third sternites are separated by almost straight groove; sternite 8 not visible in ventral view.

First male pleopod is sinuous, slender and longer than second; distal part is markedly rolled, hook like or S-shaped and tip elongated with numerous sub distal spines (Plate IV n).

Color: Carapace, dorsal surface of chelipeds and walking legs of dry specimens are whitish-yellowish color with scattered red blotches. Thumps and fingers are dark brown.

Habitat: Upper borders of the intertidal zone under and among small rocks, coral rubbles, dead coral colonies, rocky cobbles, oyster banks, and underneath broken shells at muddy shores and mangroves.

Status: Very common.

Distribution:

Local: Red Sea, Gulfs of Suez and Aqaba, as well in Lake Timsah and Suez Canal (Monod, 1938; El Sayed, 1992).

World: This species occurs in the Indian Ocean and Arabian Gulf (Davie, 1989; Cooper, 1997; Apel, 2001; Ghory et al., 2013; Naderloo, 2017).

Remarks: The present specimens are in well agreement with those mentioned by Naderloo (2017). Davie (1989) indicated that P. convexus and P. salomonensis may be synonymous and reported that two taxa are very close. However, in the present specimens, the anterolateral margins of carapace have 3 distinct lobes, decreasing in size posteriorly with sharper third lobe. Small chelae have pointed tip than large chela.

Genus: Pilumnus Leach, 1815

Pilumnus incanus (Forskal, 1775)

Synonyms:

Cancer incanus Forskal 1775: 92.

Pilumnus forskalii, H. Milne Edwards, 1834; -Nobili 1906b: 274.

Pilumnus incanus, Klunzinger 1913: 259, Fig. 16, tab 7, Figs. a-d; -El-Sayed, 1992: 45;- Ng and Clark 2005: 11; -Ng et al. 2008: 141 (list); -Naderloo and Turkay 2012: 38; -Naderloo 2017: 314, Fig. 26.22b, 26.23 and 26.24.

Material examined: 4 ( 3 males and one female).

Localities:

Red Sea Proper: Mangrove Safaga: 17 km south Safaga: RCAZUE-Crus-Br.640401-

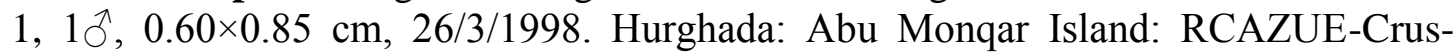
Br.640401-2, 20̂, 1.60-1.88 cm (CL), 2.12-2.58 cm (CW), 13/4/1999. Wadi El Gimal: $50 \mathrm{~km}$ south Maras Alam (St.1): RCAZUE-Crus-Br.640401-3, 19, 1.16×1.57 cm, 17/4/1996. 


\section{Morphological characters:}

Carapace is hexagonal to transversely oval, broader than long, beings 1.4 breadth on length; dorsal surface of carapace has distinct granules; carapace and appendages are markedly covered with long setae but never thick, enable to visible or seen lateral margins of carapace (Plate II, a). Anterolateral margins are provided with 4 teeth, the first tooth is smallest (Plate III, 1), and are separated from posterolateral margins with obvious distinct junction. Front not markedly produced and is slightly convex without furrow in medial; no distinct lobule between frontal lobe and inner orbital angle (Plate III, d).

Chelipeds are similar, semi equal and have scattered granules on dorsal surface of merus and carpus but palms have five rows of transversally granules (Plate IV, d).

Walking legs have long setae on dorsal surface of merui, carpuli, propodi and dactyli; dactylus has acute tip (Plate V, d).

Abdomen of male consists of freely 7 segments; with extended telson beyond half of fused sternites 3-4 (Plate V, h).

First male pleopod is S-shaped with scattered setae on first third; distal third has tuft setae and short palp (Plate IV, o).

Color: Carapace and dorsal surface of chelipeds and legs varied from brown to brownish color, with deep orange or dark red irregular spots scattered on carapace particularly on frontal, gastric, cardiac and anterolateral branchial regions. Finger and thumbs are dark brown.

Habitat: Occurs under small rocks, cobbles and coral rubbles at the intertidal rocky substrates.

Status: Rare.

Distribution:

Local: Red Sea only (Forskal, 1775; Klunzinger, 1913; El-Sayed, 1992).

World: Arabian Gulf (Naderloo and Türkay, 2012), Gulf of Oman (Naderloo et al., 2015) and Northwestern Indian Ocean (Ng and Clark, 2005; Ng et al. 2008; Naderloo and Türkay, 2012; Naderloo, 2017).

Remarks: The characters of the present specimens are in agreement with those mentioned by Naderloo (2017), but have orange to dark red patches widespread randomly on carapace. Anterolateral margin has four distanced teeth; the first tooth is shorter than other teeth.

Pilumnus longicornis Hilgendorf, 1878

\section{Synonyms:}

Pilumnus longicornis Hilgendorf 1878: 794, pl. 1, Figs 8, 9; -Nobili 1906a: 135; Balss 1933: 15; -Stephenson 1946: 144, 145, Fig 36a; -Guinot 1967: 274 (list); Jones 1986: 163, pl. 48; -Tirmizi and Ghani 1996: 68-70, Fig 26; -Apel 2001: 99;Naderloo and Sari 2007: 344, tab 1; -Ng et al. 2008: 142 (list); -Naderloo and Türkay 2012: 37; -Naderloo et al. 2013: 449, tab 1; -Naderloo, 2017, p. 315, Figs. 26.22c, 26.23, 26.25.

Material examined: Two specimens (male and female).

\section{Localities:}

Gulf of Suez: Ain Sokhna: Al Semad beach, $27 \mathrm{~km}$ south Suez City: RCAZUE-CrusBr.640402-1, 1ठ, 1ㅇ, 0.67-0.92 cm (CL), 0.93-1.25 cm (CW), 27/7/1997.

\section{Morphological characters:}

Carapace is hexagonal to transversely oval, beings 1.36 breadth on length. Carapace and appendages are covered with long setae, never thick, where lateral margins can visible or seen. Dorsal surface of carapace is smooth, without granules but has small 
granules on branchial and hepatic regions, covered with relatively scattered short setae (Plate II, d).

Anterolateral margins are convex and have 4 teeth; first tooth is the smallest; while posterolateral margins are straight. Exorbital angle has small tooth and from 3-5 small teeth are found between exorbital angle and second anterolateral tooth; second tooth of anterolateral margin has three to four small dentition on each side (Plate III, m).

Frontal margin is less projecting and less convex with furrow in med-line (Plate III, e).

Chelipeds are similar, unequal, swollen, and have small granules scattered on dorsal surface of merus and carpus; palms possess granules on upper third or superior margins only (Plate IV, e).

First male pleopod is S-shaped, strongly convex from tip and naked, while distal third has scattered short setae (Plate IV, p).

Color: Carapace and legs are yellowish to light yellow. Thumbs and fingers have light brown color.

Habitat: This species lives in the intertidal zone under stones and coral rubbles.

Status: Rare.

Distribution:

Local: Red Sea and Suez Gulf (Nobili, 1906 a; Balss, 1933; Guinot, 1967; Fouda, 2000).

World: Indo-West Pacific regions included Arabian Sea, Arabian Gulf and Gulf of Oman (Naderloo and Sari, 2007; Naderloo and Turkay, 2012; Naderloo et al., 2013; Naderloo, 2017).

Remarks: The characters of the present specimens are in agreement with those mentioned by Naderloo (2017), but upper and proximal margins of external surface of chelipeds have granules; movable fingers are shorter than thumbs. Anterolateral margins of carapace have four distinct teeth; the first is the shorter while the second is the sharper.

\section{Pilumnus minutus (De Haan, 1835)}

Synonyms:

Cancer (Pilumnus) minutus De Haan, 1835: 50, pl. 3, Fig. 2.

Pilumnus minutus, Takeda and Miyake, 1968: 40, 41, Fig 9d-e;- Titgen, 1982: 252 (list);- Apel, 2001: 99;- Naderloo and Sari, 2007: 344, tab 1; - Ng et al., 2008: 142 (list);- Naderloo, 2017: 316, Fig. 26.22d, 26.23 and 26.26.

Pilumnus hirsutus, Stimpson, 1858: 37;- Alcock, 1898: 197;- Stephenson, 1946: 146, Fig 36d-f.

Material examined: Two specimens (males only).

\section{Localities:}

Red Sea proper: Marsa Arekie: $18 \mathrm{~km}$ north- Maras Alam: RCAZUE-CrusBr.640403-1, 1 đ, $0.43 \times 0.58 \mathrm{~cm}, 8 / 7 / 1996$.

Gulf of Suez: Eastern Shores- Ras Matarma: RCAZUE-Crus-Br.640403-2, $1 \hat{\jmath}$, $0.38 \times 0.50 \mathrm{~cm}, 20 / 7 / 1993$.

\section{Morphological characters:}

Carapace is hexagonal in shape and transversely oval, beings 1.35 breadth on length. Carapace and appendages are covered with long setae, but lateral margins can easily visible or seen; regions of carapace are ill defined, with smooth granules (Plate II, c). No spines were found on infraorbital margins and hepatic regions. Anterolateral margins beings slightly convex, with 3 teeth, while posterolateral margins is nearly straight; exorbital angle without well-developed spine-shaped tooth, but no small teeth between exorbital angle and second anterolateral tooth (Plate III, n). Frontal margin is 
slightly straight, less projecting and bilobed; without separation between front and supraorbital angles (Plate III, f).

Chelipeds are unequal, semi-swollen and similar with acute cutting margins; upper border of superior margins of palm has acute granules (Plate IV, $\mathrm{f}$ ).

Abdomen of male is similar with above of Pilumnus species (Plate V, h).

Color: Carapace, chelipeds and walking legs are yellowish to light yellow. Thumbs and fingers have light brown color.

Habitat: It occurs in the shallow subtidal rocky and cobble areas.

Status: Rare.

Distribution:

Local: Red Sea and Gulf of Suez (Klunzinger, 1913; Guinot, 1967; Vine, 1986).

World: Arabian Gulf and Gulf of Oman (Stephenson, 1946; Naderloo and Sari, 2007) and Indian Ocean (Miyake, 1968; Ng et al., 2008).

Remarks: The characters of the present specimens are in agreement with those mentioned by Naderloo (2017). However, upper margin, proximal portion of fingers and external surface of chelipeds have obvious spines; movable fingers are shorter than thumbs.

Pilumnus propinquus Nobili, 1905

Synonyms:

Pilumnus propinquus Nobili, 1905: 163;- Nobili 1906a: 140-142;- Nobili, 1906b: 277, pl. 10, Fig. 7;- Balss, 1933: 12;- Stephenson, 1946: 147, 206 (list);- Guinot, 1967: 274 (list);- Titgen, 1982: 252 (list);- Hogarth, 1989: 106;- Hogarth, 1994: 101;- Apel, 2001: 100;- Ng et al., 2008: 142 (list); - Naderloo, 2017: 316, Fig. 26.27 and 26.28.

Pilumnus? propinquus- Titgen, 1982: 137.

Material examined: Two specimens (males only).

Localities:

Red Sea proper: Mangroves Marsa Abu Fissi- South Shalatein: St. 3, RCAZUECrus-Br.640404-1, 10̄, 0.42×0.54 cm, 16/8/1999.

Gulf of Suez: Ain Sokhna: RCAZUE-Crus-Br.640404-2, $1 \overbrace{}^{\lambda}, 0.62 \times 0.90 \mathrm{~cm}$, 7/8/1995.

\section{Morphological characters:}

Carapace is hexagonal in shape and transversely oval, beings broader than long, breadth averaged 1.45 on length. Carapace and appendages are covered with long setae, never thick to hide lateral margins; regions ill defined, without granules (Plate II, d).

Anterolateral margins have 4 acute spines; the first spine is the smallest. Anterolateral margin is shorter than posterolateral margin, being 0.6; exorbital angle has welldeveloped spine-shaped tooth; there is a distinct hepatic spine beings visible from dorsal view between exorbital angle and second anterolateral tooth (Plate III, o).

Frontal margins are slightly convex, with a deep V-shaped notch with dentate edges; supraorbital margins are acute (Plate III, g).

Large and small chelipeds have 4 rows of spines or acute granules covering outer surface of palm. Cutting margins of fingers and thumbs are less acute (Plate IV, g \& $\mathrm{k})$.

Walking legs are elongated and covered with short and scattered setae (Plate V, e)

First male pleopod is slender, naked and like S-shaped with a brush of hairs at its tip (Plate IV, q).

Color: Carapace, chelipeds and walking legs are light yellow to yellowish color. Chelipeds fingers and thumbs are dark brown color. 
Habitat: This species lives at rocky substrates under small stones and coral rubbles at rocky shores and mangroves.

Status: Rare.

\section{Distribution:}

Local: Red Sea and Gulf of Suez (Nobili, 1906 a, b and Guinot, 1967).

World: Arabian Gulf, Gulf of Oman and western Indian Ocean (Guinot, 1967; Titgen, 1982; Hogarth, 1989, 1994; Apel, 2001; Ng et al., 2008; Naderloo, 2017).

Remarks: The characters of present specimens are in well agreement with those mentioned by Naderloo (2017), except frontal margin appear as two lobes with obvious dentate.

Pilumnus vespertilio (Fabricius, 1793)

\section{Synonyms:}

Cancer vespertilio Fabricius, 1793: 463.

Pilumnus vespertilio, H. Milne Edwards, 1834: 418; - Alcock, 1898: 192;- Nobili, 1906b: 274;- Bouvier, 1915: 258;- Balss, 1924: 11;- Gruvel, 1936: 145, pl. 23, Fig. 34;- Barnard, 1950: 263, Fig. 49a-b,- Sankarankutty, 1962: 144;- Sakai, 1965: 157, pl. 78, Fig. 1;- Dai \& Yang, 1991: 364, Fig. 176(3), pl. 49(1);- Naderloo, 2017, P. 319, Figs. 26.22f, 26.28, 26.30.

Pilumnus ursulus, Adams \& White, 1848: 45, pl. 9, Fig. 6;- Klunzinger, 1913: 263, pl. 6, Fig. 17, pl. 11, Fig. 3.

Actaea dentate, Edmondson, 1935: 29, Fig. 9, pl.1B.

Material examined: 34 (23 males and 11females).

Localities:

Red Sea proper: Ras Mohamed Protected Area: RCAZUE-Crus-Br.640405-1, 10, $0.51 \times 0.63 \mathrm{~cm}, 23 / 7 / 1994$; St. 5: 2へ, 1 + $, 0.63-0.70 \mathrm{~cm}(\mathrm{CL}), 0.71-0.90 \mathrm{~cm}(\mathrm{CW})$, 7/1994. Wadi El Gimal: St. 1, RCAZUE-Crus-Br.640405-2, 1ㅇ, 1.26×1.52 cm, 17/4/1996. Hosam Helmy Beach: $18 \mathrm{Km}$, north Marsa Allam, RCAZUE-CrusBr.640405-3, 1 + , $1.03 \times 1.42 \mathrm{~cm}, 18 / 4 / 1996$. Al Jawly Beach: $9 \mathrm{Km}$, north Marsa Alam, RCAZUE-Crus-Br.640405-4, $1 \hat{\jmath}, \quad 0.37 \times 0.55 \mathrm{~cm}, 19 / 4 / 1996$. Ghosoon: Mangrove north Abu Ghosoon, RCAZUE-Crus-Br.640405-5, 50, 0.43-0.77 cm (CL), 0.61-1.14 cm (CW), 16/4/1996. Sharm Al Naqa: RCAZUE-Crus-Br.640405-6, $3{ }^{\Uparrow}$, 0.45-1.18 cm (CL), 1.24-1.38 cm (CW), 19/9/1996. Gabal Al Taleaa: RCAZUE-CrusBr.640405-7, 20, 0.38-0.60 cm (CL), 0.48-0.78 cm (CW), 18/9/1996. ShalateinMarsa Shia'b: RCAZUE-Crus-Br.640405-8, 1ð, 0.40×0.54 cm, 28/11/2018.

Gulf of Aqaba: Abu Galuom Protected Area: St. 12, RCAZUE-Crus-Br.640405-9, 10̂, 1ㅇ, 0.92-1.28 cm (CL), 1.21-1.61 cm (CW), 24/7/1993. Ras Abu Galuom: RCAZUE-Crus-Br.640405-10, 10, 0.86×1.12 cm, 7/1994. Napq Protected Area: St. 18, RCAZUE-Crus-Br.640405-11, 1 , $0.40 \times 0.51 \mathrm{~cm}, 7 / 1993$; RCAZUE-CrusBr.640405-12, 1 , 0.80×1.10 cm, 11/2015; Al Monkatea: RCAZUE-Crus-Br.64040513, 20, 0.39-0.50 cm (CL), 0.48-0.60 cm (CW), 28/11/1994; Al Gharkana: RCAZUE-Crus-Br.640405-14, 1ðَ, 1 ㅇ, 0.55-0.56 cm (CL), 0.68-0.69 cm (CW),

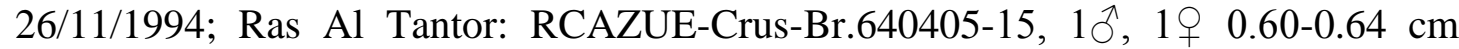
(CL), 0.70-0.86 cm (CW), 26/11/1994; North Ras El Tantor: RCAZUE-CrusBr.640405-16, 20, 1 ㅇ 0.55-0.57 cm (CL), 0.76-0.82 cm (CW), 26/11/1994.

Gulf of Suez: El-Semad and El-Khema Beaches: 27 km North Suez City: RCAZUECrus-Br.640405-17.

\section{Morphological characters:}

Carapace is broader than long, averaged 1.26 times as broad as long, beings convex anteriorly and depressed posteriorly; covers with thickly long setae hide completely lateral margins; regions are covered with a patch of granules interspersed with short 
setae between regions (Plate II, e). Anterolateral margin is slightly shorter than posterolateral margin, beings 0.7 on posterior length; it armed with 4 teeth, first is the smaller and not sharper than other teeth, while second tooth is triangular, third tooth is sharp and fourth tooth is the sharpest (Plate III, p). Front is deflected; front breadth is less than one-third breadth of carapace, represents 0.2 in length and cut into 2 lobes by a median notch, each has a distinct and prominent supraorbital angle (Plate III, h). Chelipeds are similar, asymmetrical, semi equal and covered with long setae. Merus is covered with granules on outer surface, while palm when devoid of hairs bearing beaded granules in lower half of outer surface. Fingers have irregular obtuse teeth along cutting edge (Plate IV, h).

Ambulatory legs are depressed, covered with long setae, their dactylus ends with a cuticle claw (Plate V, f).

Male abdominal telson is bluntly triangular (Plate $\mathrm{V}, \mathrm{h}$ ).

First male pleopod is slender and long, arched ventrally in middle and has a hookshaped apex (Plate IV, r).

Color: Carapace and dorsal surface of chelipeds and ambulatory legs are brownish to brown; fingers and thumbs are deep brown, while, setae are whitish to yellowish white.

Habitat: It occurs under stones and among dead coral colonies in subtidal rocky zones and mangroves.

Status: Very common.

Distribution:

Local: Red Sea, Gulf of Aqaba, Gulf of Suez and Suez Canal Lakes (Nobili, 1906; Klunzinger, 1913; Balss, 1924,1933; Guinot, 1967; Vine, 1986; El-Syed, 1992, 1996; Fouda, 2000 and Fouda et al. 2003).

World: Indo-west Pacific regions including Arabian Sea, Arabian Gulf and Gulf of Oman (Alcock, 1898; Barnard, 1950; Guinot, 1967; Sankarankutty, 1962; Naderloo, 2017).

Remarks: The characters of the present specimens are in well agreement with those reported on the same species by Naderloo (2017). However, palm has rows of variable sized- granules at dorsal surface only. Chelipeds fingers are convex and as long as thumbs. First male pleopod has setae on two sides at their tip and ends with elongated palp (Plate IV, r).

Genus: Tiaramedon Chia \& Ng, 1998

Tiaramedon spinosum (Miers, 1879)

Synonyms:

Ceratocarcinus spinosus Miers, 1879: 27, pl. 5, Fig. 11; - Balss, 1924: 2;- Serene et al., 1958: 174 (key), 176, 234, Fig. 4E, 5, pl. 5; - Guinot, 1967: 299, 312 (list);Fishelson, 1973: 467, Fig. 4b; - Fishelson, 1974: 188, Fig. 10; - Sakai, 1976: 300, Fig. 168; - Serene et al., 1976: 16; -Hwang \& Yu, 1980: 153, pl. 4, Fig. 3; - Miyake, 1983: 56, 212(list), pl.19, Fig. 6. Stevcic, et al. 1988, 1308, 1318.

Tiaramedon spinosum Chia \& Ng, 1998: 508, Fig. 7-8.

Material examined: Only one specimen (female).

Localities:

Red Sea: Ras Mohamed Protected Area: Marsa Breaka: RCAZUE-Crus-Br.640501-1, 1 , $, 1.35 \times 2.25 \mathrm{~cm}, 7 / 2016$.

\section{Morphological characters:}

Carapace is squarish in shape, slightly broader than long, beings 1:1.66 breadth on length); regions well defined; protogastric, metagastric, branchial and cardiac regions are strongly produced into dorsally directed spines. Carapace is smooth, densely 
covered with short and stiff setae. Six spines are prominent on the carapace divided into two rostral, two epigastric and two laterals branchial. Length of spines varies, protogastric spines are always the longest (Plate I, e). Anterolateral and posterolateral margins are clearly demarcated; anterolateral margin sublamelliform and entire without trace of teeth or lobes; while posterolateral margin is straight (Plate I, e). Frontal lobes are very short, triangular in shape, narrow, strongly deflexed downwards and appear beak-like from the dorsal view. Inner supraorbital teeth well developed, long and produced well beyond and obscuring most of frontal margin (Plate I, e).

Chelipeds are smooth, densely covered with short and stiff setae; merus and basiischium are unarmed; carpus and propodus with distal spines; superior margin of palm with distinct elongate tooth; finger not carinate; thumb not bent downwards (Plate I, e).

Ambulatory legs are unarmed and densely covered with short and stiff setae. Merus of all ambulatory legs has strong tooth on distal part of upper margin (Plate I, e).

Color: Carapace, ventral surfaces, chelipeds and walking legs are whitish to crime with have dark brown stripes on all.

Habitat: It lives associated with sea feather (echinoderms: crinoids).

Status: Very rare.

Distribution:

Local: Red Sea (Balss, 1924; Fishelson, 1973). It is the first record from the Egyptian Red Sea coasts.

World: Indo-west Pacific from Christmas Island and Japan (Chia \& Ng, 1998; Sakai, 1976a; Miyake, 1983) to Indonesia, Taiwan, Australia Papua New Guinea-Madang and New Caledonia (Chia \& Ng, 1998; Serene et al., 1976).

Remarks: The characters of this specimen agree with the description given by Chia \& $\mathrm{Ng}$ (1998) and $\mathrm{Ng} \&$ Jeng (1999). However, dorsal surface of carapace has 10 spines, 6 of them spines are large and distributed 2 on frontal region, 2 on protogastric regions and 2 on outer border branchial regions; while other 4 spines were found and represented by one on middle of metagastric regions, 1 on cardiac region and 2 on the inner border of branchial regions.

\section{DISCUSSION}

Species of families Pilumnidae and Galenidae (Pilumnoidea: Decapoda: Crustacea) recorded from the Egyptian Red Sea coasts and its associated gulfs (Suez and Aqaba) were revised during the present study. Remarks on the differences between given characteristic features of the recorded species and those mentioned previously were discussed after all given information on each species. These results indicated that, a total of 10 species were obtained belong to families Galenidae and Pilumnidae and distributed within 6 genera, comprised Actumnus, Cryptopilumnus, Halimede, Pilumnopeus, Pilumnus and Tiaramedon. Family Galenidae was represented by only one species (Halimede tyche); while Pilumnidae was represented by 9 species dominated with genus Pilumnus with 5 species ( $P$. incanus, $P$. longicornis, $P$. minutus, $P$. propinquus and $P$. vespertilio), while other four genera had only one species for each and comprised Actumnus asper, Cryptopilumnus pereiodontus, Pilumnopeus convexus, and Tiaramedon spinosum.

The systematic position of Tiaramedon spinosum had been treated intensively. The differences and similarities in morphological features and characteristic of larvae and number of larval stages for this species and other species of subfamily Eumedoninae had been treated by Stevcic et al. (1988) and all results exhibiting those 
members of this subfamily are more closely to family Pilumnidae than family Parthenopidae. $\mathrm{Ng}$ et al. (2008) had discussed all previous literature dealt with the position of family Eumedonidae, and ascertained that, Eumedonidae considered as subfamily within Pilumnidae. Furthermore, future molecular investigations can define the exact position of this subfamily (Eumedoninae).

The obtained results showed that, Cryptopilumnus pereiodontus considers the first record from the entire Red Sea, while Tiaramedon spinosum is recorded for the first time from the Egyptian Red Sea waters. The other pilumnid crabs were recorded previously from the Red Sea by several authors either from the Egyptian coasts by Calman (1927), Fox (1927), Grüvel (1936), Ramadan (1936), Monod (1938), Holthuis (1956), Por and Ferber (1972), El Sayed (1992, 1996a,b), Fouda (2000), Fouda et al. (2003), or from the neighbor areas in the Western Indian Ocean by Barnard (1950) Arabia Gulf and Gulf of Oman by Naderloo (2017), or recorded among true crab lists of the Red Sea pilumnid (Guinot, 1967; Vine, 1986). But some of the previously recorded species from the Gulf of Suez as Eurycarcinus natalensis (Fouda, 2000), and Actumnus miliaris (Monod, 1938) didn't record during the present study.

The number of recorded pilumnid species in the present study considers higher than those previously recorded from the Egyptian Red Sea waters. Ramadan (1936) recorded only two species (Actumnus asper and Pilumnus vespertilio) from Hurghada (northern Red Sea), while Monod (1938) recorded 7 pilumnid species belong to 3 genera under family Xanthidae from the Suez Gulf and northern Red Sea in addition to Suez Canal, comprised genus Pilumnus included Pilumnus forskalii (a synonym for $P$. incanus), $P$. longicornis and $P$. savignyi) genus Actumnus included A. miliaris and A. asper, and Pilumnopeus included P. laevis (a synonym for Heteropanope laevis) and P. vauquelini. On the other hand, Fouda (2000) recorded 4 species comprised Halimede ochtodes (a synonym for $H$. tyche), Eurycarcinus natalensis, Pilumnus vespertilio and $P$. longicornis from the northwestern coasts of the Suez Gulf, while El-Sayed (1996a,b) and Fouda et al. (2003) recorded only two species (P. vespertilio and $P$. longicornis) from the Protected areas at South Sinai (Ras Mohamed and Nabq Protected Areas) and Red Sea from Hurghada to Shalatein. On the other hand, Heteropanope laevis, Pilumnopeus vauquelini, and Pilumnus savignyi were recorded from Suez Canal Lakes by Calman (1927) and Fox (1927), Grüvel (1936) Monod (1937, 1938), Holthuis (1956), and Por and Ferber (1972), and El -Sayed (1992) as well as $H$. tyche from Suez Canal by Osman (2015).

Consequently, the obtained results had increased the entire Red Sea pilumnid fauna into 24 species based on lists constructed by Guinot (1967) and Vine (1986) and increased the Egyptians Red Sea waters pilumnid into 12 species which represent about $50 \%$ of the entire Red Sea pilumnid species.

Generally, the number of pilumnid species was varied throughout the Indo-west Pacific regions. Barnard (1950) reported four genera of pilumnid crabs comprised, Actumnus, Eurycarcinus, Parapilumnus and Pilumnus. While Garth and Kim (1983) recorded 29 species belong to 8 general of Pilumnid crabs in Philippine Islands and adjacent waters of them Pilumnus minutus and Pilumnus longicornis were recorded. While Guinot (1967) and Vine (1986) listed 23 species of pilumnid crabs within 10 genera from the Red Sea, of them Actumnus asper, Pilumnus longicornis, $P$. propinquus and $P$. vespertilio were recorded.

During the last century, pilumnid crabs were treated as subfamily under family Xanthidae. Serene (1984) promoted subfamily Pilumninae to family Pilumnidae and divided it into five subfamilies comprised Halimedinae, Heteropanopeinae, 
Heteropilumninae, Pilumninae, and Planopilumninae in a constructed key only. However, $\mathrm{Ng}$ et al., (2008) promoted family Pilumnidae to superfamily Pilumnoidea and divided it into three families comprised Galenidae which consists of four subfamily (Denthoxanthinae, Galeninae, Halimedinae and Parapanopinae), Pilumnidae comprised five subfamily (Calmaniinae, Eumedoninae, Pilumninae, Rhizopinae and Xenophthalmodinae) and Tanaochelidae consists of only one subfamily (Tanaochelinae). Based on the last updating classification, Naderloo (2017) recorded 28 species of superfamily Pilumnoidea within families Galenidae (3 genera and 3 species) and Pilumnidae (13 genera and 25 species) from the Arabian Gulf.

Consequently, at the present time, superfamily Pilumnoidea had treated in several articles around the world and covered fast regions in the Indo-west Pacific and Indian Oceans including Red Sea. These results indicated that, about 399 species within 3 families comprised Galenidae (with 4 genera and 12 species), Pilumnidae (70 genera and 358 species) and Tanaochelidae (only one genus and 2 species) were recognized.

Out of the Red Sea recorded pilumnid crabs, it is obvious that, Actumnus asper, Pilumnus longicornis, $P$. propinquus and $P$. vespertilio have wide range out of their distribution in the Indo-west Pacific areas (Barnard, 1950; Garth and Kim, 1983; Naderloo, 2017). Furthermore, Heteropanope, laevis, Pilumnopeus vauquelini, and Pilumnus hirstus from Pilumnidae and Halimede tyche from Galenidae had penetrated to Mediterranean Sea and reached coasts of eastern Mediterranean and even, Tunisia (Steinitz, 1967, Galil, 2000; CIESM, 2008). In addition to the previous mentioned northwards invasive pilumnid (Eurycarcinus integrifrons de Man, 1879) recorded for the first time as an alien species from the Egyptian Mediterranean Sea in front of Port Said during May 2016 by Abdelsalam et al. (2018). However, no evidence on this species was recorded during the present study.

In spite of these obtained results, the Egyptian coasts of the Red Sea are still in need for further intensive works particularly at deeper water to cover all different habits for all species of super family Pilumnoidea and other occurred true crabs.

\section{REFERENCES}

Abdelsalam, Kh.; Mona, M. H.; El-Gamal, M. M.; Shoukr, F. A. and Nour, ElDan, M. F. (2018): First record of Brachyuran crab Eurycarcinus integrifrons de Man, 1879 from the Egyptian Mediterranean Sea. Cah. Biol. Mar. 59: 367-377.

Adams, A. and White, A. (1848): Crustacea. In: A. Adams, the Zoology of the voyage of H.M.S. Samarang under the command of Captain Sir Edward Belcher during the years 1843-1846, pp. i-viii + 1-66, pl. 13.

Alcock, M. B. (1898): The Brachyura Cyclometopa. Part I. The Family Xanthidae. Materials for a carcinological fauna of India, No. 3. Journal of the Asiatic Society of Bengal, 67 (2): 67-233.

Apel, M. (2001): Taxonomie und Zoogeographie der Brachyura, Paguridea und Porcellanidae (Crustacea: Decapoda) des Persisch-Arabischen Golfes. Unpublished Ph.D. Thesis, Johann Wolfgang Goethe-Universität, Frankfurt am Main, 268 pp.

Balss, H. (1933): Beitrage zur kenntnis Gattung Pilumnus und verwandter Gattungen. Capita Zoologica, 4(3): 1-47. 
Balss, H. (1924): Die Parthenopiden, Cyclound Catometopen. Die Decapoden des Roten Meeres III. Expedition S. M. Schiff "Pola" in das Rote Meer. Nordliche und sudliche Halfte. Zoologische Ergebnisse 34. Denkschr. Akad. Wiss. Wien, math, naturwiss. K L, 99: 1-18.

Barnard, K. H. (1950): Descriptive catalogue of South African Decapod Crustacea. Ann. South African Mus., 38: 1-837, Fig. 1-154.

Barnard, K. H. (1955): Additions to fauna-list of South African Crustacea and Pycnogonida. Annals of the South African Museum, 43(1):1-107.

Bouvier, E. L. (1915): Decapodes marcheurs (Reptantia) et Stomatopodes, recueillis a l'ile Maurice par M. Paul Carie. Bull, scient. Fr. Belg., (7) 48 (3): 178-318 [1-141], Figs 1-42, pls. 4-7.

Calman, W. T. (1927): Report on the Crustacea Decapoda (Brachyura). Zoological Results of the Cambridge Expedition to the Suez Canal, 1924. XIII. Trans. zool. Soc. Lond., 22: 211-217.

Chia, D. G. B. and Ng, P. K. L. (1998): A revision of Ceratocarcinus White, 1847, and Harrovia Adams \& White, 1849 (Crustacea: Decapoda: Brachyura: Eumedonidae). Raffles Bull. Zool. 46: 493-563.

CIESM (2008): Atlas of exotic Crustaceans- list in the Mediterranean Sea. pp. 1-3.

Cooper, R. T. (1997): Mangal-associated Brachyura (Ocypodidae, Grapsidae, Portunidae, Majidae, Xanthidae and Leucosiidae) from the north-eastern coastal Islands of Abu Dhabi, United Arab Emirates. Crustaceana, 70:155-179.

Dai, A. Y. and Yang, S. L. (1991): Crabs of the China Seas.pp. 21+608, Figs. 1-295, pls. 1-74, China Ocean Press, Beijing and Springer-Verlag, Berlin.

Dana, J. D. (1851): On the Classification of the Cancroidea. American Journal of Science and Arts (2) 12: 283-29.

Davie, P. J. F. (1989): A re-appraisal of Heteropanope Stimpson, and Pilumnopeus A. Milne Edwards (Crustacea: Decapoda: Pilumnidae) with descriptions of new species and new genera. Memoirs of the Queensland Museum, 27(2): 129-156.

Davie, P. J. F. and Ghani, N. A. (1993): A new species of Pilumnopeus (Crustacea: Decapoda: Pilumnidae) from Pakistan. Raffles Bull Zool. 41:61-65.

Edmondson, C. H. (1935): New and rare Polynesian Crustacea. Occ. Pup. Bernice P. Bishop Mus., 10 (24): 3-40, Fig. 1-11, pl. 1-2.

El-Sayed, A. A. M. (1992): Some biological studies on some brachyuran crabs (Crustacea) from Suez Canal. Ph. D. Thesis, Zoology Dept., Faculty of Science, Al-Azhar University, 1992, 241 pp.

El-Sayed, A. A. M. (1996a): Brachyuran crabs South Sinai coasts, Gulf of Aqaba, Red Sea, Egypt. Al-Azhar Bull. Sci., 7(1):685- 698.

El-Sayed, A. A. M. (1996b): The horizontal zonation of brachyuran crabs in the shallow water coasts of the northern Red Sea and Gulf of Aqaba, South Sinai, Egypt. J. Fac. Educ., 21: 221-235. 
Fabricius, J. C. (1793): Entomologia systematica emendata et aucta secundum classes, ordines, genera, species adjectis synonimis, locis, observationibus, descriptionibus. 2: i-viii, 1-519. Hafniae.

Fishelson, L. (1973): Ecology of the crinoids of the northern Red Sea with emphasis on epi- and endozoic fauna associated with them. Jour. Mar. Biol. Assoc. India, 15(2): 461-473.

Fishelson, L. (1974): Ecology of the northern Red Sea crinoids and their epiand endozoic fauna. Marine Biology, 26, no. 2,183-192.

Forskal, P. (1775): Descriptiones Animalium Avium, Amphibiorum, Piscium, Insectorum, Vermium; quae in Itinere orientali observavit. Petrus Forskal. Post Mortem Auctoris editit Carsten Niebuhr. Adjuncta est material Medica Kahirina. 9, xxxiv, 164 pp., 1 map. Hafniae.

Fouda, M. M. A. (2000): Biological and ecological studies on some crustacean decapods from the Suez Gulf. M. Sci. Thesis, Zoology Department, Faculty of Science, Azhar University, Cairo.

Fouda, M. M.; El-Sayed, A. A. M. and Fouda, F. M. (2003): Biodiversity and Ecology of Crustacean Fauna in the Mangal Ecosystems along the Northwestern Red Sea Coast of Egypt. Al-Azhar Bull. Sci. (in press).

Fox, H. M. (1927): Appendix to the Report on the Crustacea Decapoda (Brachyura). In: Zoological Results of the Cambridge Expedition to the Canal, 1924. Trans. zool. Soc. Lond., 22: 217-219.

Galil, B. S. (2000): Halimede tyche (Herbst, 1801) (Decapoda; Xanthoidea; Halimedinae) from the Mediterranean coast of Israel, with a review of the genus. Jour. Crustac. Bio. 20(5):325-331.

Garth, J. S. and Kim, H. S. (1983): Crabs of the family Xanthidae (Crustacea: Brachyura) from the Philippine Islands and adjacent waters based largely on collections of the U.S. Fish Commission steamer Albatross in 19081909. Journal of Natural History, 17:663-729.

Ghani, N. and Tirmizi, N. M. (1992): Occurrence of four Xanthid (Brachyura) crabs in Karachi waters (northern Arabian Sea). Pak. J. Mar. Sci., 1:3747.

Ghory, F.; Ng, P. K. L. and Kazmi, Q. B. (2013): On the identities of Pilumnopeus convexus Maccagno, 1936, and P. salomonensis Ward, 1942, from the Indian Ocean, with a note on $P$. riui Takeda, 2001(Decapoda, Brachyura, Pilumnidae). Crustaceana 86(3):301-312.

Gruvel, A. (1936): Contribution a l'etude de la Bionomie generale et de l' exploitation de la faune du Canal de Suez. Mem. Inst Egypte, 29: 1-255.

Guinot, D. (1967): La faune carcinologique (Crustacea Brachyura) de l'Océan Indien occidental et de la Mer Rouge. Catalogue, remarques biogéographiques et bibliographie. In: Réunion de Spécialistes C.S.A. sur les Crustacés, Zanzibar 1964. Mém. I.F.A.N., 77: 237-352.

Haan, H. M. De. (1833-1849): Crustacea. In: P. F. von Siebold, Fauna Japonica, sive Descriptio animalium, quae in itinere per Japoniam, jussu et auspiciis superiorum, qui summum in India Batavia imperium tenent, suscepto, annis 1823-1830 collegit, notis, observationibus a adumbrationibus illustravit. Lugduni Batavorum, fasc. 1-8: I-xxi+vii- 
xvii+ix-xvi+1-243, pls. 1-55, A-Q, circ., pl. 2. (For publication dates see Sherborn \& Jentink, 1895; Holthuis, 1953; Holthuis \& Sakai, 1970).

Hellal, A. M.; El-Sayed, A. A. M. and Abu Zied, M. M. (1997): The macroinvertebrate fauna of Nabq Mangal Area, Wadi Kid, South Sinai, Egypt. Al-Azhar Bull. Sci., 8 (1): 205-222.

Herbst, G. F. W. (1782-1804): Versuch einer Naturgeschichte der Krabben und Krebse nebst einer systematischen Beschreibung ihrer verschiedenen Arten. Berlin \& Stralsund: (Band I: 1782-1790, 1274 pp. Band II: 1796, 1226 pp. Band III: 1799-1804, 1216 pp).

Hilgendorf, F. (1878): Die von Herrn. Peters in Moçambique gesammelten Crustaceen Monatsbericht de Königlich Preussischen Akademie der Wissenschaften zu Berlin 1878:782-851.

Hogarth, P. J. (1989): The Marine Crustacea of Dhofar, Southern Oman. J.Oman Studies, 10: 99-124.

Hogarth, P. J. (1994): Brachyuran crabs (Xanthoidea: Xanthidae, Pilumnidae, Menippidae and Trapeziidae) of Southern Oman. Tropical Zoology 7: 93108.

Holthuis, L. B. (1956): Notes on a collection of Crustacea Decapoda from the Great Bitter Lake. Egypt, with a list of the species of Decapod known from the Suez Canal. Zool. Meded. Leiden., 34 (22): 301-330, Fig. 1-3.

Hsueh, P. W.; Huang, J. F. and Ng, P. K. L. (2009): On a new genus and new species of pilumnid crab from Taiwan, and the generic placements of Heteropanope changensis (Rathbun, 1909) and Pilumnopeus pereiodontus Davie and Ghani, 1993 (Crustacea: Decapoda: Brachyura). Journal of Natural History, 43:323-334.

Hwang, J. J. and Yu, H. P. (1980): A fauna-list of the Crustacea from Lan-Yu Island. Ann. Taiwun Mus., 23: 151-180, pls. 1-12.

Jones, D. A. (1986): A field guide to the sea shores of Kuwait and the Persian Gulf. University of Kuwait, Blanford Press.

Klunzinger, C. B. (1913): Die Rundkrabben (Cyclometopa) des Roten Meeres. Nova Acta Leop. Carol, 99 (2): 97-402.

Leach, W. E. (1815): The Zoological Miscellany; being descriptions of new, or interesting animals, illustrated with coloured Figures, drawn from Nature, by R. P. Nodder \& c. London. E. Nodder \& Son, V1. 2: 145-154, pls. 116120.

Maccagno, T. (1936): Crostacei di Assab. Decapodi Stomatopodi Anfipodi. In: Spedizione del Barone Raimondo Franchetti in Dancalia (1828-29). Am. Mus. Stor. izat. Genova, 59: 171-186.

Miers, E. J. (1879): On the classification of the Maioid Crustacea or Oxyrhyncha, with a synopsis of the families, subfamilies, and genera. Journal of the Linnean Society, Zoology, London, 14: 634-673, pls. 12, 13.

Milne Edwards, A. (1867): Descriptions de quelques espèces nouvelles des Crustacds Brachyoures, Aizrtls Soc. Ent. Fr., sér. 4, 7 (4): 263-288.

Milne Edwards, H. (1834-1837): Histoire naturelle des Crustacés comprenant l'anatomie, la physiologie et la classification de ces animaux. Paris, 
Librairie Encyclopédique de Roret. Vol. 1: i-xxxv, 1-468. Vol. 2: 1-531. Atlas, 1837: 1-32, pls. 1-42. Vol. 3, 1840: 1-638.

Miyake, S. (1983): Brachyura (crabs). Japanese crustacean decapods and stomatopods in color: vol. 2, viii + 277 pp., pls. 1-64, Tokyo.

Monod, TH. (1937): Crustacés. In: Missions A. Gruvel dans le canal de Suez. I. Mém. Inst. Emvfe. 34: 1-19.

Monod, TH. (1938): Decapoda Brachyura. Mission Robert Ph. Dollfus en Egypte. VIII. - Mem. Inst. Egypte, 37: 91-162.

Naderloo, R. (2017): Atlas of crabs of the Persian Gulf. Springer, p. 289-324.

Naderloo, R. and Sari, A. (2007): Subtidal crabs of the Iranian coast of the Persian Gulf: new collections and biogeographic considerations. Aquat Ecosyst Health Manage, 10: 341-349.

Naderloo, R. and Turkay, M. (2012): Decapod crustaceans of the littoral and shallow sublittoral Iranian coast of the Persian Gulf: faunistics, biodiversity and zoogeography. Zootaxa, 3374: 1-67.

Naderloo, R.; Turkay, M. and Sari, A. (2013): Intertidal habitats and decapod (Crustacea) diversity of Qeshm Island, a biodiversity hotspot within the Persian Gulf. Mar Biodivers, 43: 445-462.

Naderloo, R.; Ebrahimnejad, S. and Sari, A. (2015): Annotated checklist of the decapod crustaceans of the Gulf of Oman, northwestern Indian Ocean. Zootaxa, 4028: 397-412.

Naderloo, R.; Ebrahimnejad, S.; Doostali, A. H. and Mahdian, M. (2016): Five Brachyuran crabs of the families Xanthidae and Pilumnidae (Crustacea: Decapoda: Brachyura) from Abu Musa Island, Iran; new records for the Persian Gulf. Mar Biodivers Rec 9:19.

Ng, P. K. L. and Clark, P. F. (2000): The Indo-Pacific Pilumnidae XII. On the familial placement of Chlorodiella bidentata (Nobili, 1901) and Tanaocheles stenochilus Kropp, 1984 using adult and larval characters with the establishment of a new subfamily, Tanaochelinae (Crustacea: Decapoda: Brachyura). Journal of Natural History, 34: 207-245.

Ng, P. K. L. and Clark, P. F. (2005): The Indo-West Pacific Pilumnidae XVIII: On the taxonomy of Pilumnus scabriusculus Adams and White, 1849, and P. sluiteri De Man, 1892, with a note on Cancer incanus Forskal, 1775 (Brachyura: Xanthoidea). Zootaxa, 841: 1-14.

Ng, P. K. L.; Guinot, D. and Davie, P. J. F. (2008): Systema Brachyurorum: Part I. An annotated checklist of extant brachyuran crabs of the world. Raffles Bulletin of Zoology, 17: 1-286.

Nobili, G. (1905): Décapodes nouveaux des côtes d'Arabie et du Golfe Persique (Diagnoses préliminaries). Bulletin du Muséum national d'histoire naturelle, Paris, 1905(3): 158-164.

Nobili, G. (1906a): Crustaces decapodes et stomatopodes. In: Mission J. Bonnier et Ch. Perez (Golfe Persique, 1901). Bull. Sci. France et de la Belgique, 40:13-159.

Nobili, G. (1906b): Faune carcinologique de la Mer Rouge. Decapodes et Stomatopodes. Ann. Sc. Natu., (Zoologie), (9) 4: 1-347. 
Osman, M. M. M. (2015): Study on the applied biology of some noncommercial crabs from the Suez Canal M. Sc. Thesis, Marine Science, Fac. Sci. Port Said Univ., pp. 174.

Por, F. D. and Ferber, I. (1972): The Hebrew University Smithsonian Institution collections from the Suez Canal (1967-1972). Isr. Jor. Zool., 21(3-4): 144-166.

Ramadan, M. M. (1936): Report on a collection of Stomatopoda and Decapoda from Ghardaqa, Red Sea. Bull. Fac. Sei. Egypt Univ., 6: 1-43, pi. 1, 2.

Rathbun, M. J. (1910): Brachyura. In: The Danish Exped. to Siam 1899-1900. K. Danske Vidensk. Selsk. Skr., (7) 5 (4): 301-367, Fig. 1-44, pl. 1-2.

Ruppell, W. P. E. S. (1830): Beschreibung und Abbildung von 24 Arten kurzschwdnzigen Krabben, als Beitrag zur Natugeschichte des rolhen Meeres. Frankurt a.m., H. L. Bronner: 1-28, pls. 1-6.

Sakai, K. (1999): J. F. W. Herbst-collection of decapod Crustacea of the Berlin Zoological Museum, with remarks on certain species. Naturalists, Publications of Tokushima Biological Laboratory, Shikoku University, 4: 1-45, pls. 1-21.

Sakai, T. (1965): On two new genera and five new species of xanthoid crabs from the collection of His Majesty the Emperor of Japan made in Sagami Bay. Crustaceana, 8: 97-106, Figs. 1-4.

Sakai, T. (1976): Crabs of Japan and the Adjacent Seas. In three volumes; English Text, pp. xxix+773 pp., Japanese Text, pp. 1-461, Plates volume, pp. 1-16, pls. 1-251. Kodansha Ltd., Tokyo.

Sankarankutty, C. (1962): On Decapoda Brachyura from rhe Andaman and Nicobar Islands: 2. Family Xanthidae. Journal of the Marine Biological Association of India 4: 121-150.

Serene, R. (1984): Crustacés Décapodes Brachyoures de l'océan Indien Occidental et de la Mer Rouge, Xanthoidea: Xanthidae et Trapeziidae. Avec un addendum par Crosnier (A.): Carpiliidae et Menippidae. Faune tropicale, XXIV: 1-400, Fig. A-C+1-243, pl. I-XLVIII.

Serene, R.; Duc, T. V. and Luom, N. V. (1958): Eumedoninae du Viet-Nam (Crustacea) (avec un nibliographie de la sousfamille). Treubia, 24(2): 135-242, pls. 4-7.

Serene, R.; Romimohtarto, K. and Moosa, M. K. (1976): Hippidea, Brachyura and Stomatopoda of the Rumphius Expedition II. In: Report of the Rumphius Expedition II (January 15- February 8, 1975). Oseanologia di Indonesia, 6: 15-21.

Steinitz, H. (1967): A tentative list of immigrates via the Suez Canal. Isr. Jor. Zool., 16: 116-169.

Stevcic, Z.; Castro P. and Gore, R. H. (1988). Re-establishment of the Family Eumedonidae Dana, 1853(Crustacea: Brachyura). J. Nat. Hist., London, 22: 1301-1324.

Stephenson, K. (1946): The Brachyura of the Iranian Gulf. With an appendix: The male pleopoda of the Brachyura. Danish Scientific Investigations in Iran. K. Jessen \& R. Spärck, editors. Part 4 [1945], pp. 1-237. 
Stimpson, W. (1858): Prodromus descriptionis animalium evertebratorum quae in Expeditione and Oceanum Pacificum Septentrionalem, a Republica Feberata Missa, Cadwladaro Ringgold et Johann Rodgers ducibus, observavit et descriptorum. Pars V, Crustacea Ocypoidea. Proceedings of the Academy of Natural Sciences of Philadelphia 1858: 93-110 [Pages 39-56 on separate].

Stimpson, W. (1907): Report on the Crustacea (Brachyura and Anomura) collected by the North Pacific Exploring Expedition, 1853-1856. Smithsonian Miscellaneous Collections 49(1717): 1-240, pls, 1-26.

Takeda, M. and Miyake, S. (1968): Pilumnid crabs of the family Xanthidae from the West Pacific. I. Twenty-three species of the genus Pilumnus, with description of four new species. OHMU, Occasional Papers of Zoological Laboratory, Faculty of Agriculture, Kyushu University, 1(1): 1-60, pls. 1-4.

Tirmizi, N. M. and Ghani, N. (1996): Marine fauna of Pakistan: Crustacea: Brachyura, Brachyrhyncha, part 1: Xanthidae, Goneplacidae, Pinnotheridae, Ocypodidae, Grapsidae. Center of Excellence, University of Karachi, Karachi.

Titgen, R. H. (1982): The systematics and ecology of the decapods of Dubai, and their zoogeographic relationships to the Persian Gulf and the Western Indian Ocean, Ph. D thesis, Texas A \& M University, USA.

Vine, P. (1986): Red Sea Invertebrates (Vine, P. ed.), IMMEL Publishing, 224pp.

Ward, M. (1942): Notes on the Crustacea of the Desjardins Museum, Mauritius Institute, with descriptions of new genera and species. Bull. Maurit, Inst., 2 (2): 49-113, pls. 5-6. 


\section{Key to superfamilies of section Eubrachyura}

1- Male abdomen is divided into 5 segments; segments 3-5, even their sutures are sometimes visible, are fused together into a single unit. Super families Xanthoidea and Trapezioidea

-Male abdomen is divided into 6 (segments 5 and 6 are fused together) or 7 segments ........................................................................ 2 2- Length of second pleopod never exceeds that of first, but can sometimes extend beyond half of the length of first. Superfamily Pilumnoidea -Length of second pleopod extends beyond that of first, distal half usually differentiate into a filamentous flagellum Superfamilies.

\section{Carpilioidea and Eriphioidea} Superfamilies

\section{Key to families of superfamily Pilumnoidea}

-Front is prominent, nearly straight or bilobed; carapace is pentagonal, much broader than long. Abdomen of male has a very elongate telson, its length being more than twice that of greatest length of other abdominal segments............ Family Galenidae (Halimede tyche)

-Front is normal; carapace is varied from xanthoid-shaped, dorsally convex but not much broader than long, to globular or transversely oval, beings much broader than long and dorsally flattened ....

Family Pilumnidae

\section{Key to genera and species of family Pilumnidae}

1- Carapace is enlarged transversely and dorsally flattened with an enlarged posterior margin Tiaramedon (T. spinosum)

- Carapace is xanthoid-shaped, narrow and dorsally convex with a narrow posterior margin................................................................... 2 2-Anterolateral margins with lobes, never with spines, without distinct junction between posterolateral margins; carapace and upper surface of appendages covered with long setae; anterolateral margins not arched .... Heteropilumnus (*) -Anterolateral margins with lobes, teeth or spines, with distinct junction between posterolateral margins.............................................................. 3 3-Upper surface of carapace is completely glabrous, anterolateral margins with small denticles; front broadly bilobed and straight Eurycarcinus (*) -Upper surface of carapace has short or long setae with distinct spines, teeth or lobes; front has different forms

4-Upper surface of carapace and appendages without long setae or with scarce long setae; anterolateral margins without spines or not all teeth spine-shaped; distance between front and inner orbital margin without lobule or with small lobule; telson never reached half of fused sternites 3-4

-Upper surface of carapace and appendages covered markedly with long setae; anterolateral margins with spines; distinct lobule between frontal lobe and inner orbital angle; telson extended beyond half of fused sternites 3-4 .Genus Pilumnus........... 8

5- Upper surface of carapace with fine velvet form setae; posterolateral margins of carapace markedly concave ..................................................Actumnus (A. asper)

-Upper surface of carapace without fine velvet form setae, scarcely covered with long setae; posterolateral margins of carapace not concave

6- Anterolateral margins of carapace with relatively low teeth; large and small chelipeds are markedly tuberculated on upper and outer surfaces; transverse suture between sternites 1 and 2 in males indistinct Cryptopilumnus (C. pereiodontus) 
-Anterolateral margins of carapace with well grown teeth; large chelipeds are distinctly smooth without any tooth; distinct transverse suture between sternites 1 and 2 in males 7

7-Posterior surface of carapace with granular ridges, serrated by setae; regions are moderately defined; front is broadly bilobed with distinct lateral lobules Pilumnopeus (P. convexus)

- Posterior surface of carapace is relatively smooth without setae, regions are weakly defined; front is broadly bilobed without lateral lobules Heteropanope (*) 8-Carapace and appendages are thickly covered with long setae, lateral margins not visible. Pilumnus vespertilio -Carapace and appendages may cover with long setae but never thick, lateral margins can be visible

9- Dorsal surface of carapace with distinct granules

Pilumnus incanus

- Dorsal surface of carapace without granules may with small pits 10 10-Exorbital angle with small tooth; 3-5 small teeth between exorbital angle and second anterolateral tooth, second tooth of anterolateral margin with three to four small denticles; dorsal surface of carapace covered with relatively thick short setae Pilumnus longicornis

- Exorbital angle with well-developed spine-shaped tooth, no tooth between exorbital angle and second anterolateral tooth; dorsal surface without thick short setae

11-Inner part of infraorbital margin without spine; no spine on hepatic region

Pilumnus minutus

-Inner part of infraorbital margin with distinct spine; distinct hepatic spine visible from dorsal view between exorbital angle and second anterolateral teeth 12

12-Larger chelipeds with large spines covering outer surface of palm... Pilumnus propinquus

-Larger chelipeds with palm mostly smooth on outer surface ... Pilumnus savignyi (*)

Symbol $(*)$ denotes to previously recorded species either at the Egyptian coasts or from Red Sea but did not recorded during the present study. 

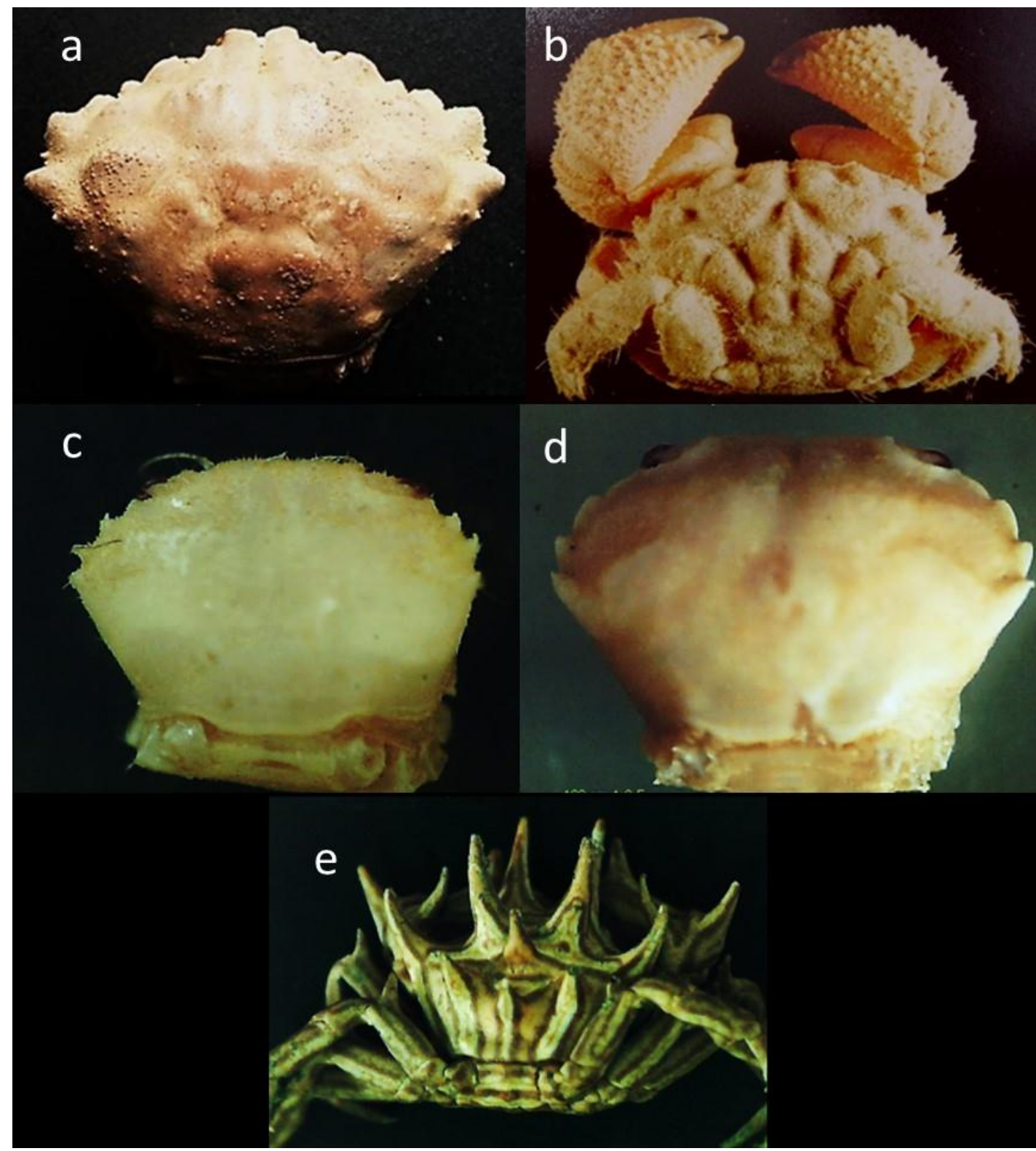

Plate I: Dorsal views for carapace: a) Halimede ochtodes (ðત, 3.9x5.20 cm), b) Actumnus asper (ð, $5.7 \times 7.7 \mathrm{~mm}), \mathrm{c})$ Cryptopilumnus pereiodontus $(\widehat{\partial}, 0.45 \times 0.70 \mathrm{~cm}), \mathrm{d})$ Pilumnopeus convexus $($, , $1.58 \times 2.42 \mathrm{~cm})$, and e) Tiaramedon spinosum $(+, 1.35 \times 2.25 \mathrm{~cm})$. 


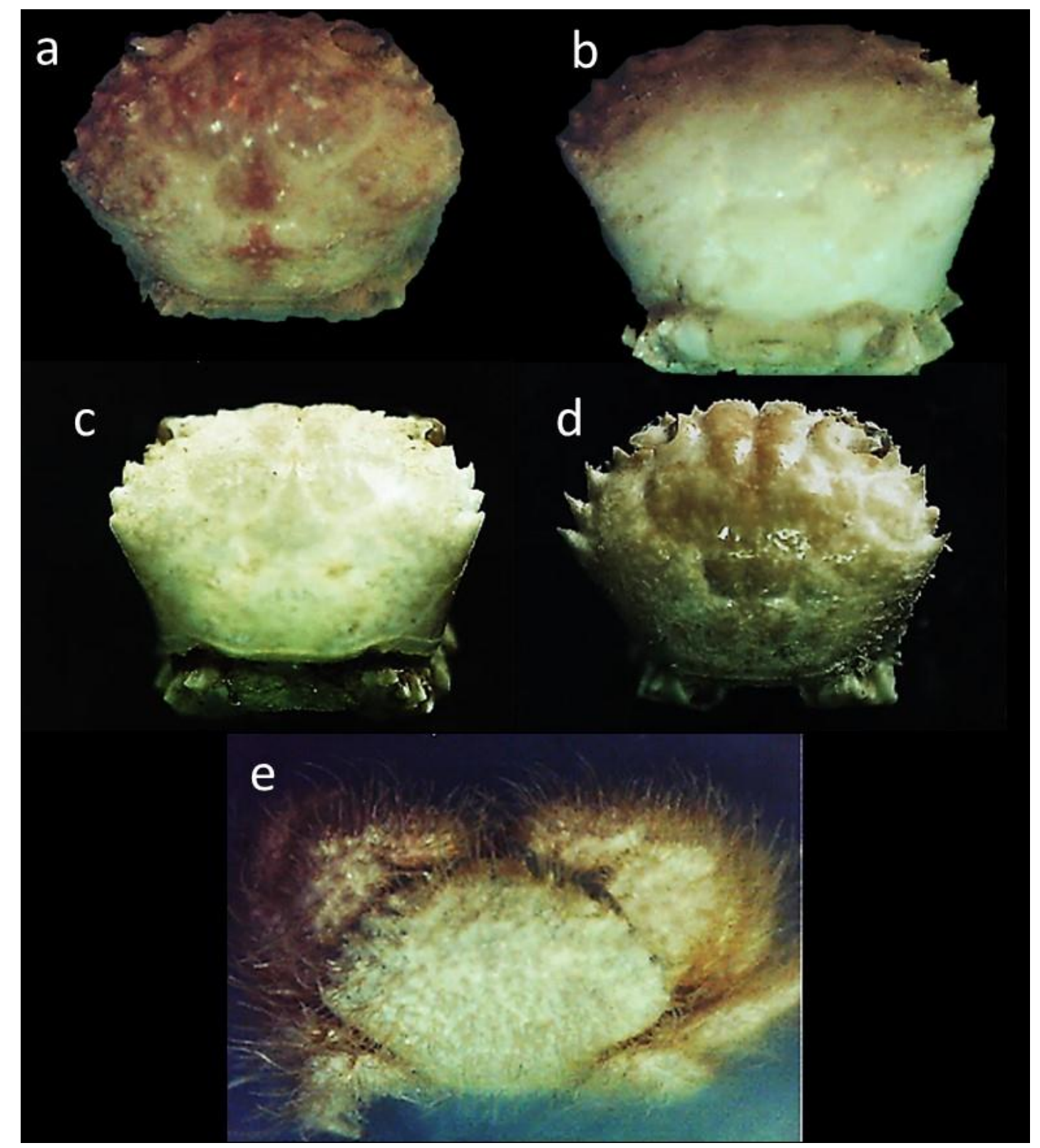

Plate (II): Dorsal views for carapace: a) Pilumnus incanus $(\bigcirc 1.88 \times 2.58 \mathrm{~cm})$, b) P. longicornis $\left({ }^{\lambda}\right.$ $0.92 \times 1.25 \mathrm{~cm})$, c) P. minutus $(\hat{\sigma} 0.43 \times 0.58 \mathrm{~cm})$, d) P. propinquus $(\widehat{\sigma} 0.62 \times 0.9 \mathrm{~cm})$, and e) $P$. vespertilio $($ ふ $1.28 \times 1.61 \mathrm{~cm})$. 


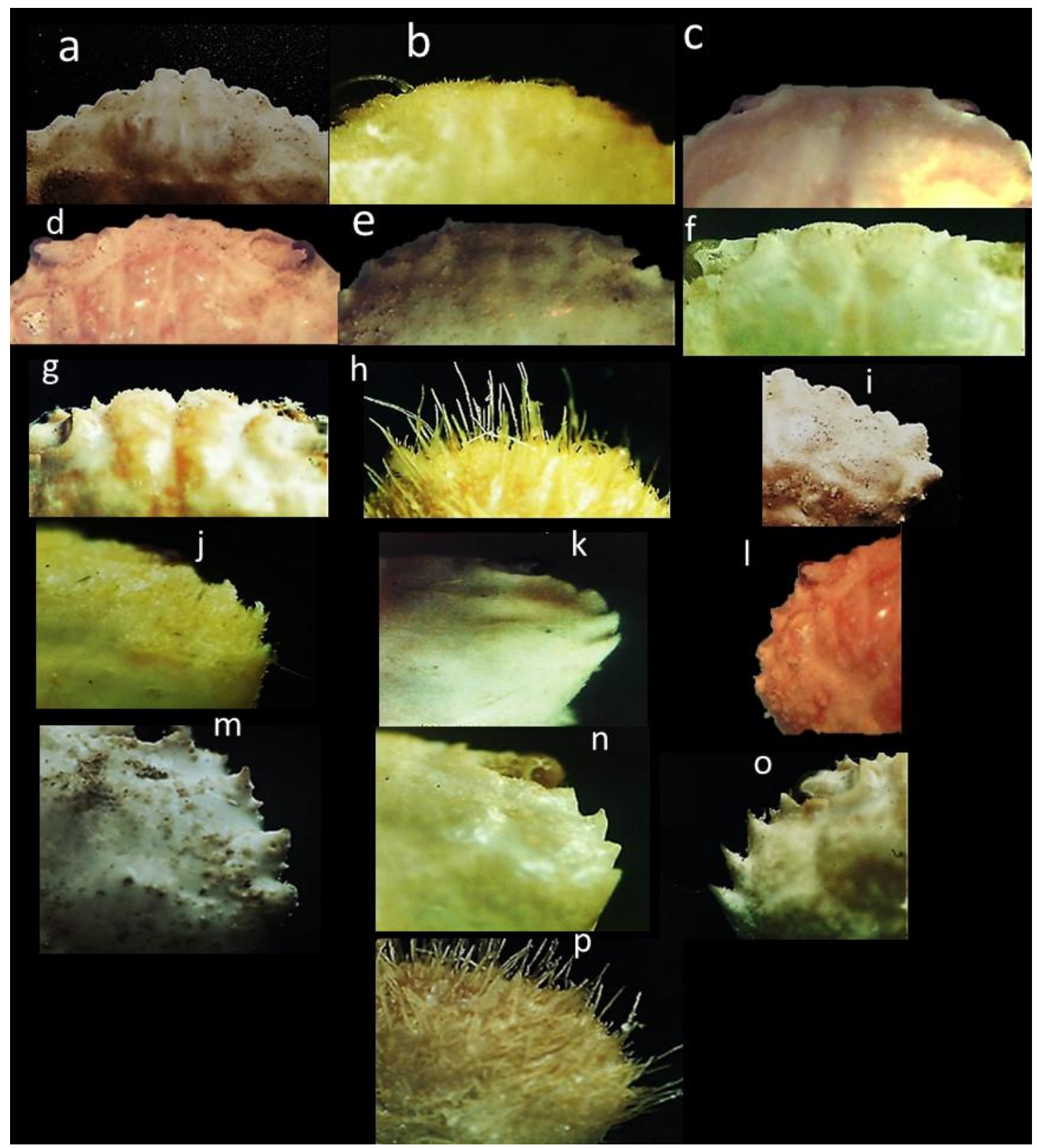

Plate III: (a-h) frontal margin and (i-p) anterolateral margin of carapace: a\&i) Halimede tyche, b\&j) Cryptopilumnus pereiodontus, c\&k) Pilumnopeus convexus, d\&l) Pilumnus incanus, e\&m) $P$. longicornis, f\&n) $P$. propinquus, g\&o) $P$. minutus, and h\&p) $P$. vespertilio respectively. 

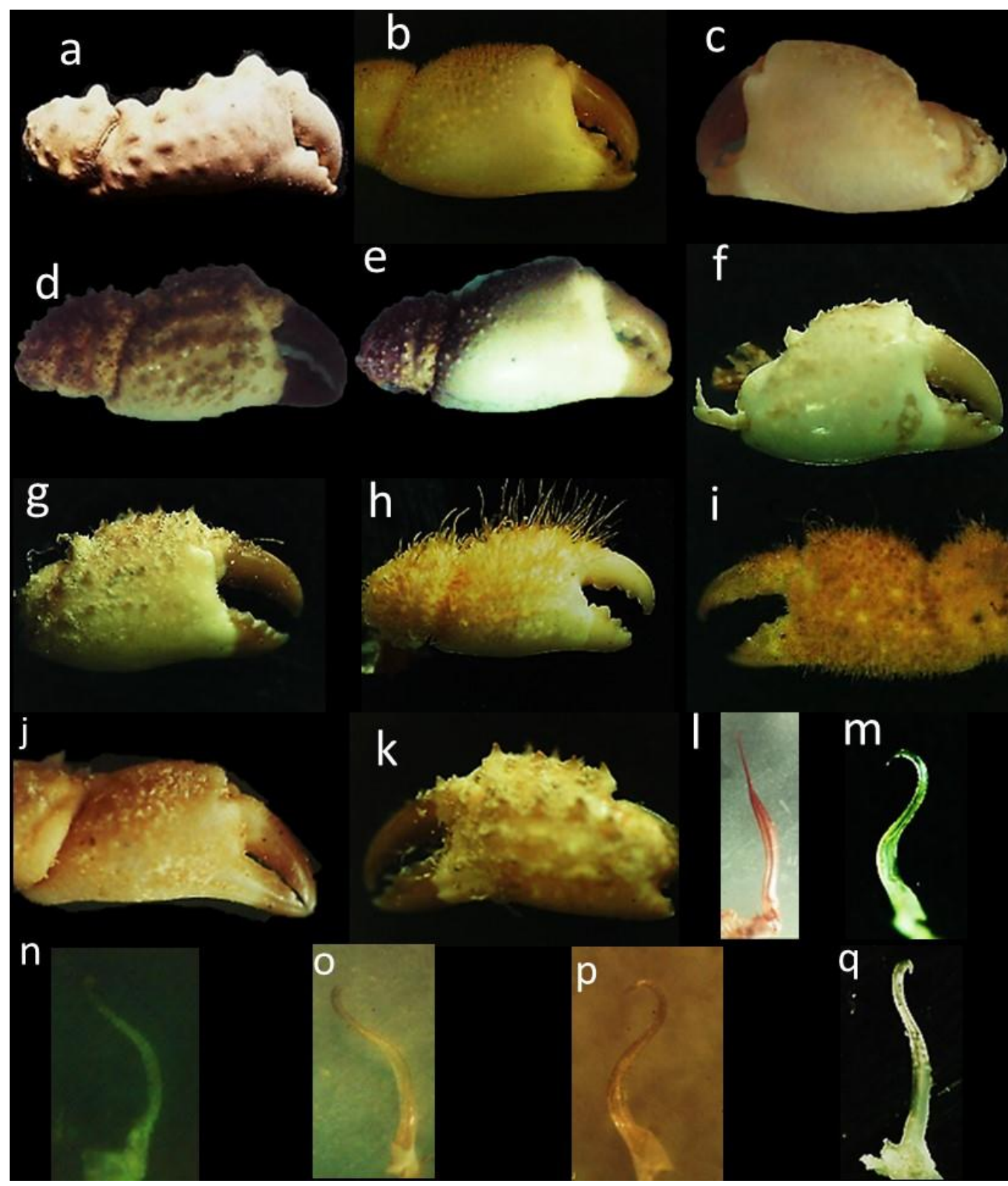

Plate IV: Outer and dorsal surface of chelae and first male pleopods: a) H. tyche, b) C. pereiodontus, c) $P$. convexus, d) $P$. incanus, e) $P$. longicornis, f) $P$. propinquus, g) $P$. minutus, and h) $P$. vespertilio respectively; (i-k) dorsal surface of small chela: i) C. pereiodontus, j) $P$. convexus and k) $P$. propinquus respectively; (1-r) first male pleopod: 1) H. tyche, m) C. pereiodontus, n) $P$. convexus, o) $P$. incanus, p) $P$. longicornis, q) $P$. propinquus and r) $P$. vespertilio respectively. 


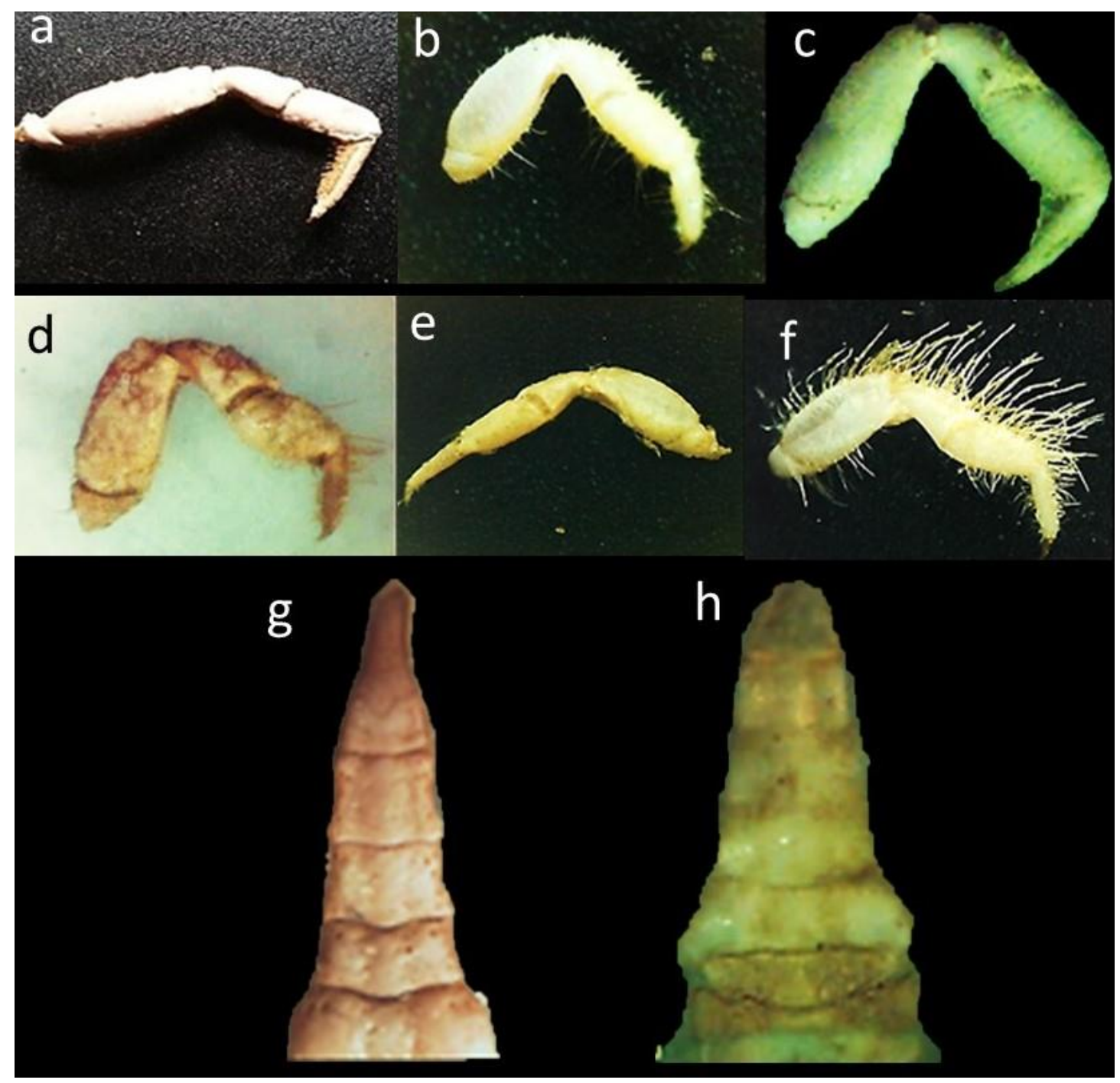

Plate V: (a-f) Walking legs: a) H. tyche, b) C. pereiodontus, c) $P$. convexus, d) $P$. incanus, e) $P$. propinquus, f) $P$. vespertilio, $\mathrm{g}$ ) male abdomen of $H$. ochtodes, h) male abdomen of Pilumnus species. 


\section{ARABIC SUMMARY}

مراجعة تصنيفية لأنواع سرطانات فوق عائلة البليومنويديا ( القشريات قصيرة الذنب) من الثواطيء المصرية للبحر الأحمر وخليجي البويس السويس والعقبهـ مصر الفر

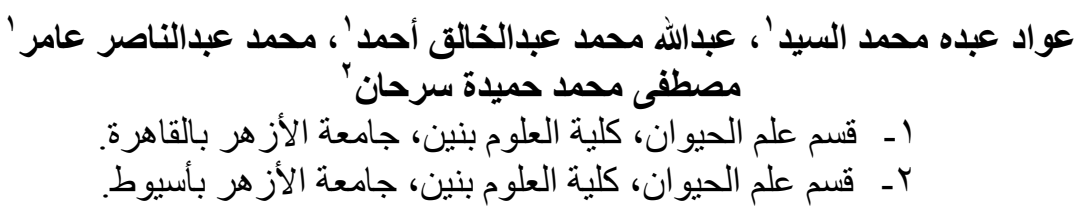

أوضحت الدر اسة تسجيل عشرة أنواع تتبع فوق عائلة Pilumnoidea من الشو اطئ المصرية للبحر

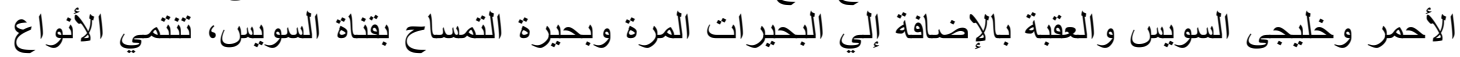

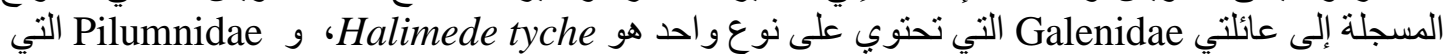

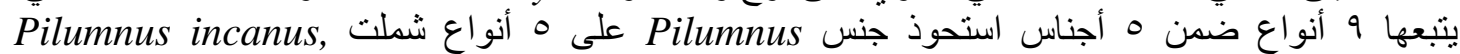
P.longicornis, P. minutus, P. propinquus, P. vespertilio الأخر جنسا منفصلا شملت: Actumnus asper, Cryptopilumnus pereiodontus, Pilumnopeus

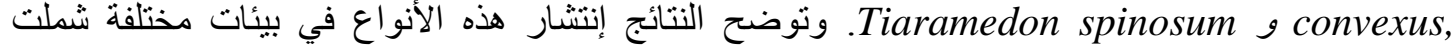

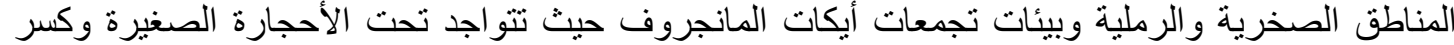

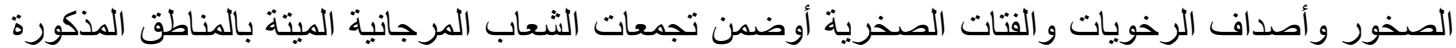

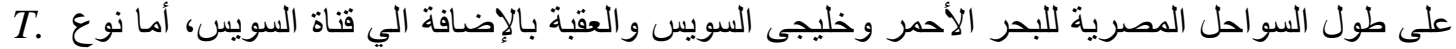

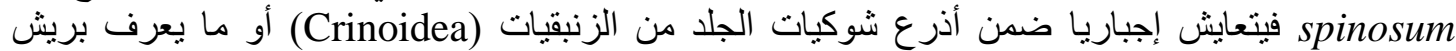

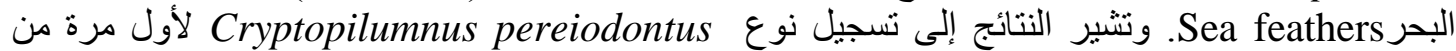

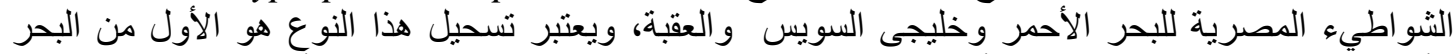

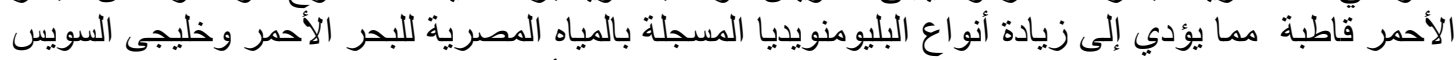

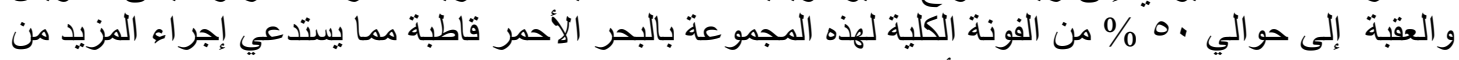
الدر اسات على هذه المجمو عة بالمياه الأكثر عمقا بالإضافة إلى استخدام تقنيات البيولوجيا الجئية الجزيئية. 